\title{
Induction of NAFLD with Increased Risk of Obesity and Chronic Diseases in Developed Countries
}

\author{
Ian James Martins ${ }^{1,2,3}$ \\ ${ }^{1}$ Centre of Excellence in Alzheimer's Disease Research and Care School of Medical Sciences, Edith Cowan \\ University, Joondalup, Australia \\ ${ }^{2}$ School of Psychiatry and Clinical Neurosciences, The University of Western Australia, Nedlands, Australia \\ ${ }^{3}$ McCusker Alzheimer's Research Foundation, Hollywood Medical Centre, Nedlands, Australia \\ Email: imartins@cyllene.uwa.edu.au
}

Received 7 March 2014; revised 5 April 2014; accepted 12 April 2014

Copyright (C) 2014 by author and Scientific Research Publishing Inc.

This work is licensed under the Creative Commons Attribution International License (CC BY). http://creativecommons.org/licenses/by/4.0/

(c) (i) Open Access

\section{Abstract}

The susceptibility of individuals to obesity has been reported in many developed countries with predisposition of humans to obesity associated with high calorie diets and unhealthy lifestyles. Obesity may closely be involved in cell suicide in various organ diseases with the importance of accelerated aging that requires early intervention with drug therapy to prevent diseases such as non alcoholic fatty liver disease (NAFLD) that has increased in children and reached to approx. $40 \%$ of the global population. Obesity is induced by various diets and lifestyle factors such as stress, anxiety and depression which are important to consider with the global increase in obesity and are possibly linked to the rise in individuals with brain disorders that involve neurodegeneration. Xenobiotics such as the endocrine disruptor chemicals that have increased in the environment in various developed countries lead to various chronic endocrine diseases as populations divert towards unhealthy diets and lifestyles with induction of NAFLD and obesity. The amount and nature of food intake that improves and increases liver lipid and xenobiotic metabolism in obese individuals have become important to decrease the risk for increased adiposity in man. High fibre or protein diets that contain leucine may improve liver glucose, lipid and xenobiotic metabolism and require further investigation with xenobiotics such as endocrine disruptors involved in appetite dysregulation and metabolic disorders in developed countries. The use of anti-obese drugs that reduce food intake and improve hypercholesterolemia and cardiovascular disease has been assessed in obesity with drug therapy closely involved either in the prevention or induction of NAFLD and obesity in man.

\section{Keywords}

Global, Induction, Obesity, Nutrition, Xenobiotic 


\section{Introduction}

The projected health care costs by the year 2018 in relation to obesity related medical expenses in the United States have been reported to be 344 billion dollars accounting for $21 \%$ of total health care costs. In particular, intra-abdominal adipose tissue referred to as visceral fat has been associated with the metabolic syndrome and obesity associated with insulin resistance and an increase in the cardiovascular risk factors such as dyslipidemia, hypertension and Type 2 diabetes [1]-[4] in women being more at risk than men in various countries. The susceptibility of humans to obesity is far higher compared with other species and in man favours the deposition of fat. Amongst mammals, humans have been reported to have the highest levels of fat than any other species and genes and environmental factors predispose humans to obesity. The global increase in obesity is linked to various induction factors such as dietary fat that override the liver's ability to metabolize lipids and determine excess body fat (adipose tissue size) with the risk of hypercholesterolemia and insulin resistance that lead to population mortality in developed countries.

In developed countries, the Western diet is known to be high in fat and glucose and associated with an increase in NAFLD and obesity [5]-[7]. There has been a rise in obesity over the past decades with the death rate from the complication of obesity in the United States to be approx. 300,000 per year. Obesity is second only to smoking as preventable cause of death and the number of obese individuals is expected to rise to approx. $42 \%$ of the population by the year 2030. The prevalence of childhood and adolescent obesity has tripled since 1980 in several age groups and the prevalence of overweight or obesity exceeds $50 \%$. In North America, the rate of childhood obesity has doubled in the last 20 years and similar statistics are reported in countries like Thailand, China, Brazil and South Africa.

Several modalities that prevent the induction of obesity have been tested which include diets, drugs, exercise and behaviour. In mice, induction of obesity has become important and the models have been created to study obesity and its co-morbidities such as Type 2 Diabetes, hypertension, hypercholesterolemia and atherosclerosis as found in man. In reports related to cardiovascular disease and threats to global health, various diets and drugs have been considered because of their ability to regulate genes linked to human adiposity that are closely linked to life extension in man [8] [9]. Early dietary intervention in obese mice models allowed reduction in the severity of visceral obesity and several chronic diseases such as NAFLD and neurodegenerative diseases [10]-[14]. Interests in the use of anti-obesity drugs have increased since successful therapy may reduce the complications such as the risks of diabetes and cardiovascular disease that have been reported with obesity. Education programs such as food restriction programs have been performed but induction of obesity has not decreased in the developed world [7]. Morbid obesity has gained attention and bariatric surgery or gastric banding has been used however the need for reoperation in these morbid individuals indicates discomfort and complications of the surgery. Interventions in obesity that reverse the induction processes allow normal gene regulation of tissues with increased lipid and xenobiotic (drugs, and chemicals) metabolism in tissues such as the liver that is central to adiposity and chronic disease progression with contribution to the global obesity epidemic.

\section{Adiposity and Obese Classifications}

Adiposity is the body fat tissue content and its increase is measured by body mass index (BMI). Obese individuals are defined as having a BMI of $>30\left(\mathrm{BMI}=\right.$ weight in $\left.\mathrm{kg} / \mathrm{m}^{2}\right)$ [height inm] whereas overweights are defined as having a BMI from $25-30 \mathrm{~kg} / \mathrm{m}^{2}$ and ideal lean individuals to have a BMI of $25 \mathrm{~kg} / \mathrm{m}^{2}$. The role of the liver and the induction of obesity early in life are of critical understanding to the development of hyperinsulinemia which may lead to diabetes and other morbid diseases such as cancer and coronary artery disease. Visceral fat is more metabolically active than peripheral fat and is associated with Type 2 diabetes, dyslipidemia, high blood pressure, and increased risk for atherosclerotic disease [8] [9]. The waist-to-hip ratio helps identify patients with excess visceral adiposity. Women with a waist-to-hip ratio $>0.8$ and men with a ratio $>1.0$ are considered to have excess central adiposity that confers risk for developing the metabolic syndrome. Morbid obesity is classified as a BMI of $>35 \mathrm{~kg} / \mathrm{m}^{2}$ and severe obesity $>40 \mathrm{~kg} / \mathrm{m}^{2}$. In the United States, the number of children and young adults affected by Type 2 Diabetes has risen and childhood obesity is now considered a major predictor of adult obesity and Type 2 diabetes.

\section{Changes in Lifestyles Lead to Adiposity and Various Chronic Diseases}

The reported epidemiological shifts in NAFLD and obesity demand elevated costs to health care in developed 
countries as well as in those that are poor and underdeveloped [14]. Excessive caloric intake, genetic, environmental inducing agents, and psychosocial factors all contribute to the cause of the reduced metabolism and development of obesity in middle adult life. In the United States, prevalence of obesity has increased from $15 \%$ in 1980 to $36 \%$ in 2010 with morbid obesity greater in women than men. In overweight individuals, obesity leads to inflammation and increased oxidative stress in the brain and periphery and has prompted intense research in the induction of various other chronic diseases in organs such as heart, pancreas, thyroid, kidneys, reproductive organs, lungs and brain [15]-[23]. Lifestyles that involve increased anxiety and stress in individuals in developed countries induce obesity with a shorter life span and worldwide approx. 2.5 million deaths result from various chronic diseases in peripheral organs with obese women more at risk than men in developed countries [24].

In the developed communities, obesity is one of the major causes of atherosclerosis, stroke [25] and heart failure with approx. $13 \%$ of individuals ending in death. In severe obese individuals, sudden cardiac death can be as high as 40 times in obese men than women and arrhythmia accounts for the mortality. Hypertension and obesity are closely linked with $42 \%$ of individuals with blood pressure dysfunction. Disorders of the pancreas are closely linked to insulin resistance with the metabolic syndrome responsible for various organ diseases such as diseases of the kidneys [22] [23], reproductive organs, lungs and thyroid (hypothyroid). Menstrual cycle disorders and infertility are closely correlated with obese women. Obese men have fertility problems with abnormal semen outputs related to endocrine alterations such as adipokines, sex steroids and insulin resistance. Respiratory diseases such as chronic obstructive pulmonary disease, asthma, obstructive sleep apnea and obesity hypoventilation syndrome are associated with obesity. The relationship between increasing obesity and decreasing total lung capacity has been reported. Hypothyroidism is linked to reduced metabolism and energy expenditure with increased adiposity in obese individuals.

In obesity, low brain volumes and central nervous system alterations are possibly associated with an increased incidence of stroke independent of other risk factors such as diabetes, hypertension and hypercholesterolemia. Body fat disturbances and their association with brain disorders have previously been assessed with regional alterations in brain structure [26] [27] and a reduction in brain volume determined by voxel based morphometry (VBM). This technique analyses the whole brain and is based upon 3D magnetic resonance imaging (MRI) with objective assessment of the neuroanatomical structure throughout the brain. Obese individuals compared with lean individuals have significantly lower gray matter density in the post central gyrus, frontal operculum, putamen and middle frontal gyrus after adjustment for sex, age, handedness and global tissue density. BMI in these obese individuals was negatively associated with GM density of the left post central gyrus in comparison with that in lean subjects. This study identified structural brain differences in human obesity in several regions of the brain that are involved in the regulation behaviour, reward and taste with increased weight gain in obesity. In childhood, obesity with the metabolic syndrome disorder changes in brain volume and structure may also indicate alterations in appetite, hypertension and insulin resistance closely associated with brain abnormalities in obese children [28]. Furthermore, the increased risk between obesity and neurodegeneration in the developed world has been shown in a 27 year longitudinal study [29].

In obese individuals, loss of brain control is poorly understood and alterations in brain circuitry or feeding signals in obesity involve abnormal hormone regulation with poor control of chronic organ disease progression. The hypothalamus is involved in many biological functions such as appetite and body weight control, feeding, rhythmic daily activities and corticosteroid regulation [10]. In obese individuals, loss of the ability of the brain to regulate body weight and energy balance is dependent on neurons in the hypothalamus and their connections to various brain regions that are abnormal in chronic neuroendocrine diseases such as in obesity and diabetes [10]. In obesity, the brain disorders include the hypothalamus with suprachiasmatic nucleus (SCN) disorders that involve the neural and humoral systems and arcuate nucleus neurons involved in the generation of circadian rhythms with releases of neuropeptide Y (NPY) and agouti related protein (AgRP) that control physiological functions such as appetite regulation and behavioural functions [10] [30]-[32]. The SCN releases a number of hormones and the SCN projects to the dorsal parvocellular paraventricular nucleus which projects to sympathetic preganglionic neurons with regulation of melatonin output from the pineal gland. Changes in lifestyle pattern, diet intake and usage of drugs induce various peripheral organ diseases, leading to disturbances in SCN neurons expressing neuropeptides [10], causing elevations in peripheral signals such as glucose, amino acids, fatty acids, cholesterol, and amyloid beta, with alterations in peripheral hormones such as leptin, adiponectin (adipose tissue) and ghrelin, that have marked effects on the brain control for appetite regulation, energy expenditure and meta- 
bolism [33]-[37]. Peripheral organ diseases such as chronic kidney disease are associated with SCN disturbances with the role of melatonin in the treatment of chronic kidney disease [38]. In particular. high fat diets and alcohol are linked with SCN disturbances and consumption of these diets induces circadian alterations in the brain linked to alterations in mental health and peripheral organ diseases. Adiposity and lifestyle changes such as circadian rhythms are linked to brain circadian disturbances induced by jet lag, lifestyles disturbances, drugs and diet [39] [40] and these environmental effects (Western countries) have become important and are now strongly linked to the development of human obesity in various developed countries. The SCN may regulate the sleep-wake cycle with effects on anxiety, stress and depression and these effects on the sleep-wake cycle have been shown to be species-specific. Sleep and chronic diseases possibly involve the hypothalamus and melanin-concentrating hormone $(\mathrm{MCH})$ that regulate metabolic homeostasis [10], sleep and wakefulness [41]. Furthermore in obesity, melatonin released from the pineal gland during the night is disrupted during sleep with sleep dysregulation [42] and loss of entrainment of the SCN [43].

Alterations in sleep patterns in health and disease are involved in changes in adiposity since disrupted sleep patterns affect the $24 \mathrm{hr}$ clock in the brain that is controlled by the SCN in the hypothalamus. Sleep deprivation may be involved in the induction of obesity [44]-[47] and has been shown to be related to the circulating levels of the appetite stimulating hormone ghrelin and leptin contents [48]. Furthermore, appetite regulating hormones such as ghrelin and leptin can influence these areas of the brain and are involved with resetting the circadian rhythms generated by the SCN. These hormonal changes in sleep-deprived adults are possibly related to increased body weight in these obese individuals. Anxiety and stress disorders may induce sleep disturbances that affect mental health that induces changes in the brain, hormone regulation and the biological clock in the body.

\section{Unhealthy Nutrigenomic Diets Accelerate NAFLD and Adiposity in Developed Countries}

The understanding of genetic factors involved in the risk for obesity has identified genes that are closely linked to obesity related diseases [49]-[52]. A single gene effect versus multiple genes effect may indicate either the interaction unique to various environments that regulate abnormal molecular or cellular events responsible for obesity with several hypotheses proposed in relation to the development of obesity [53]. The understanding of the development of adipogenesis has been the focus of various research groups with unhealthy diets that alter DNA methylation (epigenetic), genes and transcription factors important to the world-wide obesity epidemic with increased risk for adiposity. Alterations in 400 genes, single gene disorders and variants are involved in obesity with particular genes (e.g. leptin, melanocortin/Melanocortin 4 receptor, ghrelin, neuromedin $\beta$, peroxisome proliferator-activated receptor (PPAR), and mitochondrial uncoupling proteins) involved in the behaviour, metabolism, energy expenditure, taste and appetite of the organism.

The search for specific genes that are sensitive to nutritional regulation, oxidative stress, inflammation, endocrine disease, lipid/glucose metabolism and insulin resistance has been the focus of the current obesity epidemic in various developed countries. Epigenetics is now considered as an important mechanism for the development of obesity and can result from changes in cellular chromatin structure without alterations in DNA sequence, including DNA methylation, histone modifications and chromatin remodelling. Epigenetic modifications altered by unhealthy diets with increased oxidative stress or environmental factors have the ability to change gene expression with effects on cellular lipid metabolism and energy expenditure. Epigenetic modifications in Western communities are closely involved in early liver disease (NAFLD) associated with excess transfer of fat to the adipose tissue and the induction of obesity in developed countries.

Sirtuin 1 (Sirt1) is one of the nuclear receptors known to regulate several cell functions by deacetylating both histone and non-histone targets and this anti-aging gene [54] in the liver is either inhibited or suppressed in Western populations with accelerated aging of the liver (NAFLD) and profound effects on the health of other organs. Sirt1 is a $\mathrm{NAD}(+)$ dependent class III histone deacetylase (HDAC) protein that targets transcription factors to adapt gene expression to metabolic activity, insulin resistance and inflammation in chronic diseases [55]-[59]. Nutritional regulation (calorie restriction and high fat feeding) of Sirt1 that is involved in the hypothalamic control of food intake with regulation of the central melanocortin system via the fork head transcription factor has been reported [60]-[63]. Sirt1 has been closely linked with alterations in appetite regulation and circadian rhythms that have been associated with obesity and alterations in Sirtl expression and leptin levels have been associated with disruption of the daily light/dark cycle. In support of Sirtl's role in circadian rhythms 
[64]-[68] subjects carrying minor alleles at Sirt1 and CLOCK loci displayed a higher resistance to weight loss compared with homozygotes for both major alleles, suggesting links between the circadian clock and Sirtl function. Other genetic studies provide strong links between obesity and Sirtl gene polymorphisms. These genetic studies provide a greater understanding of Sirt1 polymorphisms and individuals that may be at increased risk for obesity.

Diets and nutrigenomics are involved in Sirtl regulation that is actively involved in DNA repair with transcription factors regulated by Sirt1 in obesity closely connected to the nuclear hormone receptors such as peroxisome proliferator activated receptor (PPAR), liver X receptor (LXR), pregnane X receptor (PXR), farnesoid X receptor (FXR) involved in liver metabolic and xenobiotic homeostasis [14] with roles in lipid metabolism in adipose tissue. In adipose tissue, Sirt1 triggers fat mobilisation by inhibiting peroxisome proliferatoractivated receptor gamma (PPAR-gamma), and in the pancreas, Sirt1 repression of the uncoupling protein 2 (UCP2) increases insulin secretion and also influences mitochondrial biogenesis and inflammation. Sirtuins are involved in gluconeogenesis in the liver, fat mobilisation from white adipose tissue, cholesterol metabolism, insulin secretion from the pancreas and energy metabolism. Excess calorie consumption leads to liver Sirt1 downregulation that causes liver disease (NAFLD) with the excess fatty acid and cholesterol transported to the adipose tissue and peripheral organs. The concept that high fat diets can downregulate Sirt1 levels in the liver may have important implications for the role of the liver in the induction of obesity in man with excess fat transport to the adipose tissue.

Sirt1 is involved in endocrine and somatotrophic disturbances that implicate growth hormone in insulin resistance and peripheral endocrine disease [69]-[72]. Furthermore, Sirt1 is downregulated by palmitic acid and alcohol and its low activity is involved in various chronic diseases (metabolic syndrome) of the lung, heart and kidney [73]-[75]. Cellular Sirt1 expression/activity is important in the processing of amyloid precursor protein which generates the $\mathrm{AD}$ peptide amyloid beta in neurons with links to neurodegenerative diseases. The link between obesity, food intake and amyloid beta [76] homeostasis under circadian control indicates that disturbances in the SCN in chronic diseases such as obesity and diabetes also possibly involve neurodegenerative diseases such as Alzheimer's disease (AD) and Parkinson's disease (PD).

Transcription factors and gene regulators include micro RNA (miRNAs) and their role in the induction of obesity indicates altered expression of multiple miRNAs in metabolic tissues [77]. MiRNAs 103 and 143 are important in the acceleration of adipogenesis [78] with other miRNAs such as miR-27 and miR-519d [79] by regulation of PPAR determine adipocyte development and fat cell numbers. PPAR $\gamma$ is strongly expressed in adipocytes and plays a significant role in the transcriptional activation of adipocytokines (adiponectin and leptin). $\operatorname{PPAR} \alpha$ activation causes increased lipid clearance via $\beta$-oxidation enhancement and miRNA dysregulation is important in the abnormal metabolism of adipocyte lipids and the development and severity of obesity. Dietary regulation of Sirt1 expression in adipose tissue may play a central role in NAFLD with the effects of miRNA deregulation in Sirt1 regulation involved in insulin resistance and metabolic disease [80] [81].

\section{Induction of Obesity and NAFLD in Rodent Obese Models with Relevance to Man}

Animal models of obesity resemble human obesity with hyperphagia (overeating), hyperinsulinemia, hyperlipidemia and NAFLD [82]-[91]. To assess the induction of obesity in experimental animals, confounding factors such as genetic diversity, gender, diet and age that are involved in the induction of human obesity can be controlled in animal models [91]. Mice fed a high fat diet or high fat/high sugar diet over a number of weeks become obese and insulin resistant. These obese mice are used to study the genetic and physiological mechanisms of obesity that are similar to conditions in humans. Rodent and human models for obesity vary with factors that include the species, strain, genetic models, age of animals and type and amount of fat consumed. There are several causes of obesity in rodent models and obesity may result from the excessive food intake or slow body fat metabolism (Table 1).

Obesity can be chemically induced by gold thioglucose (GTG) by development of lesions in the brain [91] and other tissues (e.g. liver, kidneys and adipose tissue). The GTG mice are hyperinsulinemic and within 5 weeks become overweight associated with a number of insulin receptors [91]. Genetic models of rodent obesity also include the obese/obese (ob/ob) mouse, fat/fat, yellow-obese mouse, diabetic (db/db) and the New Zealand Obese mouse [91]. In all models of obesity (chemically induced or genetic) in our studies, food intake markedly increased (hyperphagia) with a decrease in the hepatic metabolism of lipid particles [91]-[93]. Marked improvements in the hepatic lipid metabolism with food restriction were associated with improved plasma glucose and lipid levels indicating food restriction to be closely linked to the maintenance of hepatic lipid and glucose 
Table 1. Induction of obesity in mice with insulin resistance and organ dysfunction.

\begin{tabular}{|c|c|c|}
\hline INDUCING AGENTS & $\begin{array}{l}\text { APPETITE DISORDER } \\
\text { OXIDATIVE STRESS }\end{array}$ & $\begin{array}{l}\text { METABOLIC DISEASE } \\
\text { ORGAN DISEASE }\end{array}$ \\
\hline HIGH FAT HIGH CHOLESTEROL DIETS & YES & $\begin{array}{l}\text { PANCREAS, NAFLD, BRAIN, ADIPOSE } \\
\text { TISSUE, THYROID }\end{array}$ \\
\hline HIGH SUGAR CARBOHYDRATE DIETS & YES & $\begin{array}{l}\text { PANCREAS, NAFLD, BRAIN, ADIPOSE } \\
\text { TISSUE, THYROID }\end{array}$ \\
\hline $\begin{array}{l}\text { CHEMICAL AGENTSEg. Goldthioglucose, Eg. } \\
\text { Endocrine disrupting chemicals }\end{array}$ & YES & $\begin{array}{l}\text { PANCREAS, NAFLD, BRAIN, ADIPOSE } \\
\text { TISSUE, THYROID }\end{array}$ \\
\hline GENETIC OBESE/DIABETIC MODELS & YES & $\begin{array}{l}\text { PANCREAS, NAFLD, BRAIN, ADIPOSE } \\
\text { TISSUE, THYROID }\end{array}$ \\
\hline
\end{tabular}

metabolism. In our studies of obese mice and streptozotocin induced diabetic rats [93], the clearance of li pid particles was also markedly decreased and prevention of hyperphagia improved the clearance of lipids and lowered plasma glucose levels. In these obese mice and diabetic rats, the diet contained $5 \%$ fat (low fat) but food intake over the 6 week experimental period was twice that of the controls [92] [93]. In both chemical and genetic mouse models of obesity, the mice developed hyperphagia with nutrition stress and NAFLD and the slow liver metabolism of lipids was possibly associated with Sirtl mediated cell apoptosis associated with poor appetite control [92] [93]. Relevance to man with stable isotope breath tests showed that the poor metabolism of hepatic lipid particles was possibly linked to NAFLD and obesity in man [94]-[96]. In mouse models of obesity, induction by diet was closely linked to NAFLD in these mice [87]-[89]. The studies in obese mice, diabetic rats and obese man clearly indicated that the abnormal glucose and hepatic lipid metabolism may be closely linked to reduced hepatocellular Sirt1 activity and expression with induction of NAFLD.

Lifestyle patterns, environmental stress and diets (nature of fat/carbohydrates) may hamper the hepatic xenobiotic metabolism [14] of various pollutants such as endocrine disrupting chemicals (EDC) and drugs with close connections to disruption in energy homeostasis and increased risk for chronic disease. In experimental studies, models of lipid particles (chylomicron remnants) of different sizes that preferentially target the liver showed that the increased dose of injected lipids was related to the decreased clearance of lipid particles with possible effects on downregulation of hepatic Sirt1 activity [97]. The implications of reduced hepatic Sirt1 activity by nutritional regulation (chylomicron remnants) possibly are connected to the impaired intracellular hepatic metabolism of xenobiotics such as the EDCs [98]-[106] that is also under Sirt1 regulation [14]. Implications to diets that contain saturated fats (palmitic-rich) may lead to increased inhibition of nuclear Sirtl activity by palmitic acid [107] [108] with decreased liver xenobiotic metabolism and induction of obesity and other chronic diseases. Increased levels of xenobiotics in the plasma and various tissues [14] may lead to increased reactive oxygen species associated with low Sirtlactivity [109] [110] which is associated with obesity in developing countries. In developed countries, obese individuals may develop Sirt1 inhibition early in life that leads to liver dysfunction (NAFLD) and an increase in adipose tissue mass similar to that found in the Sirt1 knockout mouse with liver steatosis and increase in adipose tissue mass [111] [112]. In Sirt1 transgenic mice, over expression of Sirtl leads to increased hepatic metabolic activity with reduction in blood lipids and glucose [113]. In children, the rise in NAFLD and obesity may indicate that epigenetic modifications by various xenobiotics may induce NAFLD associated with excess transfer of fat to the adipose tissue. Furthermore, the increased levels of certain xenobiotics such as persistent organic pollutants (POP) may be early risk factors for the induction of NAFLD and various chronic diseases in developed countries.

\section{Endocrine Disruptors as Risk Factors for Obesity and Chronic Disease}

Adipose tissue and endocrine dysregulation have become important to the understanding of the obesity associated insulin resistance with relevance to chronic disease [10]. The link between NAFLD and endocrine disrupting chemicals with the induction of obesity has become important since most EDCs or persistent organic pollutants (POP) are fat-soluble and dietary fat may accelerate their absorption and transport to the liver for metabolism and degradation. EDC scan disrupt the metabolic and endocrine system by blocking or interfering with signals from nuclear receptors and cell receptors with the effects on endogenous hormones within various organs 
of the body [98]-[100] [103]-[105]. Endocrine organs targeted by EDCs include the reproductive organs, heart, pancreas, thyroid, parathyroid, adrenal glands, hormone dependent metabolic system (pancreas and liver) and effects on brain function. Particular interest in EDCs such as phthalates in the regulation of the PPAR gamma (nuclear receptors) in adipose tissue indicates that they play an important role in the induction of obesity [114]-[119] similar to ceramide-PPAR interactions in cellular apoptosis and insulin resistance [10] [120]. The effects of EDCs on Sirt1-PPAR (alpha or gamma) interactions and their effects on the endocrine system have been reported with endocrine disorders linked to chronic diseases connected to appetite dysregulation and behavioural disorders.

Hypercholesterolemia and xenobiotic metabolism are now closely associated with the liver as a central organ in the metabolism of EDCs, cholesterol, fatty acids, glucose and bile acids [14]. The liver nuclear hormone receptors pregnane $\mathrm{X}$ receptor (PXR) and constitutive androstane receptor (CAR) are xenobiotic nuclear receptors involved in the transcription of liver drug metabolizing enzymes and transporters [14]. The PXR receptor shows remarkable amino acid variability between species $(80 \%)$ and indicates that the role of diet may have an important influence on survival of various species [121]. The role of PXR and CAR in drug metabolism and energy homeostasis has become important to individuals in the developed world [122]. PXR knockout mice develop liver steatosis, hyperinsulinemia, hyperleptinemia and hypoadiponectinemia consistent with the metabolic syndrome [123]. The mouse models of the Sirt1 knockout or the PXR knockout indicate defects in xenobiotic and cholesterol metabolism which are possible explanations for the molecular mechanisms for induction of obesity in man and the increased global obesity epidemic.

In obese individuals, the Sirtl dysregulation associated with the defective lipid metabolism also involves the abnormal metabolism of EDCs and POP in various tissues that contain fat stores [103]. The understanding of Sirt1 regulation of PXR function [14] in xenobiotics metabolism is now required with important involvement of PXR in HDL cholesterol metabolism [124] [125]. Furthermore, the involvement of PXR in the diabetes has increased with the involvement of various PXR agonists in glucose and lipid dysregulation [126] [127]. In obesity, the brain disorders that involve the SCN regulation of the sleep-wake cycle have possible connections to Sirt1dysregulation and effects on PXR and its role on energy and xenobiotic metabolism. In obese individuals, the associated neurodegeneration is possibly related to the influence of EDCs or POP and their effects on the SCN and life cycles [14] [128] are possibly related to NAFLD with influences on adipose tissue circadian rhythms that lead to obesity. The control of chronic diseases induced by EDC disturbances depends on diets and anti-obese drugs that target Sirt1/PXR disorders (Figure 1) that are linked to the induction of obesity, cardiovascular disease and various diseases that involve the chronic endothelial injury hypothesis [129]-[136].

The P-glycoprotein 1 (Pgp1) is an adenosine triphosphate (ATP) dependent protein involved in xenobiotic transport by the export of cellular drugs across membranes in the liver, blood brain barrier (BBB), intestine and kidney [137]-[141]. Effects of Pgp in tissues include effects on lipid homeostasis with the development of NAFLD and obesity in Pgp knockout mice [142]. In the Pgp knockout mice, liver steatosis and excess adipose tissue mass was associated with metabolic disruptions [142]. The Pgp is actively involved in cholesterol transport (ABCA1

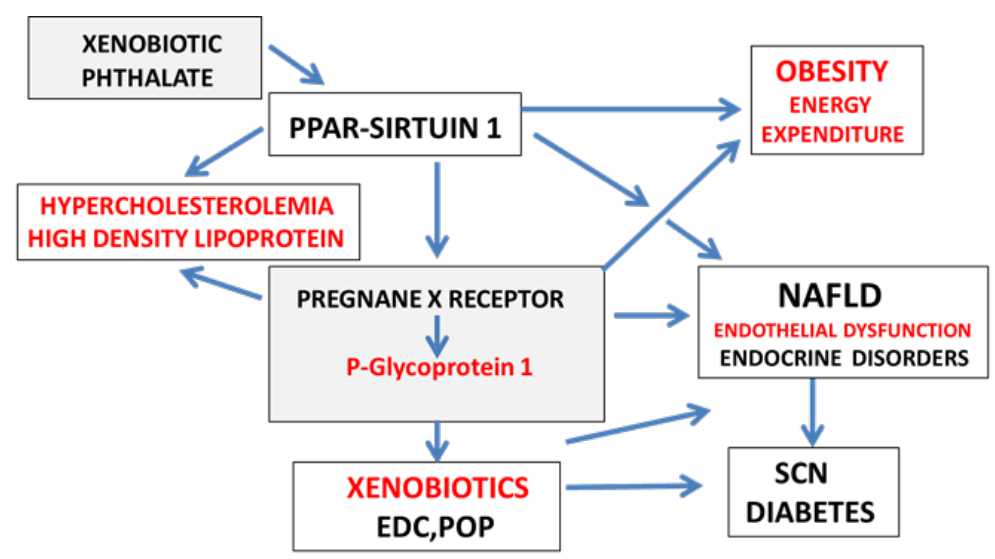

Figure 1. Xenobiotic effects on PPAR-Sirtuin 1 and Pregnane X receptor induce SCN disorders (appetite dysregulation), obesity, endothelial dysfunction and chronic disease. 
mediated) in the cell membranes with transport of cholesterol to HDL and LDL [138] [139]. In AD, upregulation of Pgp is involved in the rapid clearance of amyloid beta from the brain with implications for Pgp as a therapeutic target for amyloid beta and xenobiotic clearance in the brain [143] [144]. Upregulation of Pgp activity in the liver is involved in PXR protein levels with implications of diet on PPAR-Sirt1/PXR interactions [145] [146] involved in regulation of Pgp mediated xenobiotic clearance in chronic diseases such as the kidney. The kidney is a central organ for amyloid beta, drug and foreign compound metabolism [147]-[149] with important consequences to kidney disease associated with the obesity epidemic in children and adults [150]. Unhealthy diets that promote NAFLD may accelerate kidney disease with delayed renal clearance of amyloid beta and xenobiotics (EDCs and POP) with associated SCN dysfunction and neurodegenerative diseases.

\section{Use of Anti-Obesity Drugs with Treatment or Induction of Obesity}

Drugs that have been developed for the treatment of obesity are either involved in the reduction of energy intake or the increase of energy expenditure and their beneficial effects may include improvements in glycemic control or psychiatric illness. Interests in the use of obesity drugs have increased since safety and use of the drugs for continued weight loss (reduced visceral fat stores) have become of concern to medical authorities in Western communities [151]-[154]. The continued use of the anti-obesity drugs has been assessed in relation to diabetes and cardiovascular disease and the weight loss events have not necessarily been associated with improved medical complications in obese women that are more at risk than men in various developed countries.

Anti-obesity drug development has targeted the neurobiology of appetite [155] [156] and energy homeostasis and has different targets in the central nervous system (CNS) and peripheral nervous system (Figure 2). The role of anti-obesity pharmacotherapy is to control fat intake and reduce metabolic disorders such as the metabolic syndrome. The CNS drugs control food intake by acting on satiety by catech-cholaminergic noradrenaline and dopamine (e.g. diethylpropion, methamphetamine) pathways, 5 hydroxytrptamine pathway or combined pathways with receptors for control of satiety in the hypothalamus. Peripherally acting drugs act to reduce fat intake at the gastrointestinal tract or directly at the sympathetic nervous system by regulation of energy expenditure by thermogenesis or by lipolysis.

The use of obesity drugs and their mechanisms of action may not be complete since the understanding the brain circuits and stabilization of neuroanatomical structures in the brain has not as yet been determined. The research in understanding the use of anti-obesity drugs in the stabilization of brain structures such as frontostriatal limbic circuits, hypothalamus brainstem circuits and parasympathetic nervous system is required and information of how neuropeptides and neurotransmitters are regulated by these drugs requires further assessment. Various anti-obesity drugs that target the CNS and peripheral tissues such as the adipose tissue, liver and muscle have shown promise over the past 100 years however withdrawal of these drugs recently [157]-[159] has resulted in the avoidance of harmful side effects to various obese individuals. The discovery of novel CNS compounds that are in the early phase and are under clinical development allows for assessment of agents that allow weight reduction with alteration in serious medical complications of obesity [160]-[164].

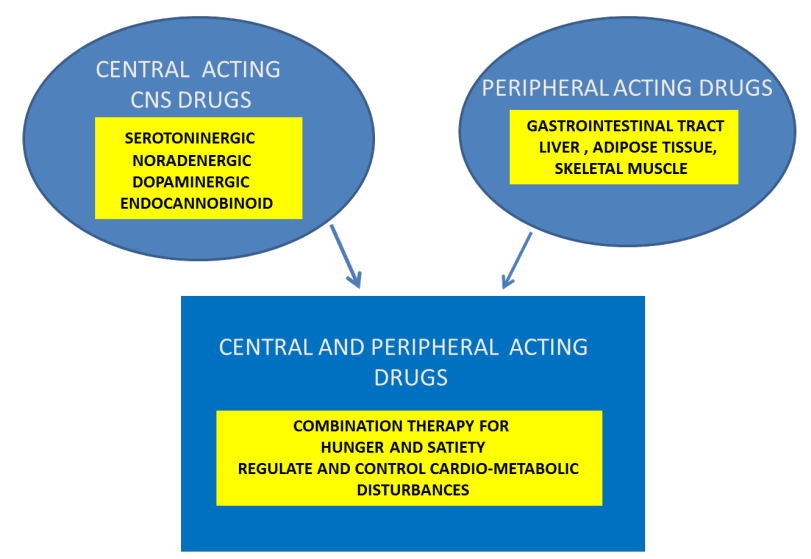

Figure 2. Anti-obese drugs act at the central nervous system or peripheral nerous system to control food intake and body weight. 


\section{Mechanisms of Anti-Obesity Drugs}

Sympathomimetic drugs act as an appetite suppressant by increasing fullness and delaying food intake. These drugs act as the neurotransmitter norepinephrine and side effects include tachycardia and increase in blood pressure and are involved in significant weight loss in various clinical trials. Sympathomimetic drugs include benzphetamine, phendimetrazine, phentermine, diethylpropion, mazindol, sibutramine and phenylpropanolamine. Psychotropic drugs include the selective serotonin uptake inhibitors (e.g. fluoxetine, sertraline, fluvoxamine, and bupropion) used for weight loss in clinical trials and the treatment of mood disorders (antidepressants and antiepileptics). Drug induced weight gain [165] also includes a systematic review of intra-class and inter-class psychotropic drugs [166]-[168] that allow poor recommendations of various psychotropic drugs involved in weight gain and the induction of obesity.

Drugs that inhibit fat absorption or digestion (pancreatic lipase inhibitors) have shown significant weight loss in obese individuals by altering metabolism of lipoproteins in the blood plasma. Weight loss was associated with decreases in low density lipoprotein (LDL) cholesterol, glucose and blood pressure (e.g. Orlistat which is a potent inhibitor of gastrointestinal lipase). Lipid digestion inhibitor (actinobacterium) inhibits the activity of pancreatic lipase one of the enzymes involved in fat digestion. Combinations in drug therapy have also been used to delay food intake and inhibit fat absorption to maintain weight loss in obese individuals. Anti-obesity drugs that treat obesity also involve the neurotransmitter receptors and currently the neurotransmitter receptors under evaluation include the cholecystokinin (CCK)1R agonist, cannabinoid receptor 1 (CB1R) inverse agonists and 5 hydroxytryptamine receptor (5HT) 2cR agonist with the $\mathrm{CB} 1$ and $5 \mathrm{HT}$ agonists indicated in human trials to induce weight loss. Neuropeptide mimetics with peptides like leptin that reduces food intake have also been evaluated.

Anti-obesity drugs that improve insulin resistance, dyslipidemia and the metabolic syndrome have not been appropriate to lifestyles, diet and health conditions and drug effectiveness has been variable without weight loss. Long term treatment of obesity with the use of anti-obese drugs particularly centrally active agents has not been achieved with safety concerns. Anti-obesity drug discovery programmes have been ineffective with improper starts, failures in clinical development, and withdrawals due to adverse effects that were never predicted from clinical trials and drug development. Removal of several of these drugs from the market [157]-[159] has allowed the introduction of other drugs such as gut based hormone treatments which target many pathways involved in the regulation of energy balance (Contrave or Emphatic). Development of new drugs that prevent NAFLD [169] and promote liver xenobiotic metabolism may manage and prevent adiposity. These new drugs that reduce xenobiotic toxicity do not pose safety concerns. The long term use of these anti-obesity drugs prevents insulin resistance, xenobiotic toxicity and the metabolic syndrome with cardiovascular safety.

\section{Nutritional Interventions Reverse NAFLD with the Prevention of Obesity}

In Western countries, the aging populations are afflicted with disorders of the SCN and appetite control that are closely related to endocrine abnormalities as observed in obesity and chronic diseases [10]. High fat foods that are consumed in these countries with low physical activity accelerate chronic diseases and neuroendocrine disturbances in these obese and aged populations leading to the global obesity pandemic. Women and children may be at greater risk for obesity in Western populations with NAFLD with the metabolic syndrome more common in these groups. Consumption and identification of food components in diets that extend life have become important with reduction in xenobiotic toxicity associated with NAFLD and chronic diseases [170]-[177].

A low calorie diet is essential and recommended for the treatment of NAFLD and obesity and the benefit of this dietary regime is quite likely to lead to Sirt1 activation with improved peripheral cholesterol and xenobiotic metabolism. Sirt1 activation may also lead to the stability of the neuroendocrine system that allows control of brain appetite centres without abnormal sensations related to hunger and behavioural disorders associated with overeating. Appropriate changes in the consumption of various foods that improve Sirt1 and PXR activation are required and Sirtl inhibitors such as alcohol should be avoided with low palmitic acid diets essential for treatment of liver disease and for rapid liver metabolism of glucose, amino acids, xenobiotics and fatty acids.

Prevention of chronic disease and activation of nuclear receptors such as Sirt1/PXR are essential for reversal of insulin resistance and endocrine disorders associated with obesity. Healthy food consumption and exercise may not eradicate the obesity epidemic or chronic diseases in the Western world since various xenobiotics being present in the food such as the phthalates which affect the nuclear receptors (PPAR-Sirt1) are possibly involved in hypothalamic disorders that are closely related to food intake and body weight [10] [14]. The role of diets that 
contain fat soluble xenobiotics needs to be determined since consumption of various low fat foods may have reduced xenobiotics and drugs [169] that reduce intestinal lipophilic xenobiotics may reverse NAFLD, insulin resistance and chronic diseases associated with obesity. Individuals from developed countries must undergo exposure assessment in developing countries [14] to avoid xenobiotic toxicity from elevated xenobiotic exposure present in food, water and air with induction of chronic disease such as obesity.

Effective diets for the prevention of NAFLD and chronic diseases utilise nutrients like methionine methylsulfonylmethane, sulphur, choline, and trimethylglycine as building blocks and allow switching of genes on and off to regulate appropriate cell function. Vitamins such as vitamin B12, folic acid, and vitamin B6 play multiple roles in the support of nuclear receptor stability. Foods that are important include eggs, cottage cheese, dairy, red meat, chicken, legumes, duck, nuts, and seeds. Consumption of fish oils (DHA/EPA) and melatonin are important to the reversal of NAFLD with the consumption of phosphatidylinositol essential for nuclear receptor liver function and the reversal of NAFLD in man. Antioxidants and minerals (magnesium, zinc) that improve genomic stability and reduce free radical damage of cells include vitamins such as $\mathrm{C}, \mathrm{D}$ and $\mathrm{E}$ essential for cell function. A lack of antioxidants leads to increased free radical damage and more risk for damage to various cells with chronic disease. Addition of resveratrol to the diet has been shown to activate Sirt1 with the prevention of NAFLD in animal models [178].

High fibre diets [179] that contain fruit and vegetables have become important for the treatment of NAFLD with the reduction in the fat content of tissues such as the liver and adipose tissue and prevention of various chronic diseases (Figure 3). Activation of nuclear receptors such as the Sirt1/PXR and G coupled receptors by calorie restriction (low glycemic index) is important to the science of nutrigenomics [179] with relevance of specific nutrients in the treatment of NAFLD and induction of obesity. Fruits such as apples contain pyruvic acid (450 mg/apple) an antioxidant that is an activator of Sirt1 [180] [181] and is essential for NAFLD treatment. Consumption of pyruvic acid has been associated with weight loss [182]-[184] with therapeutic potential to the heart and brain [185] [186]. Other foods that contain small amounts of pyruvic acid such as cheese and red wine also contain inhibitors of Sirt1 (palmitic acid and alcohol respectively). Pyruvic acid carboxylase is connected to NAFLD with inhibition of pyruvic acid carboxylase a therapy for NAFLD and induction for obesity and diabetes [187].

Excessive ingestion of vegetables not more than (1 - $2 \mathrm{gm} /$ day) may cause SCN disorders with accumulation of brain phytosterols with aging [179]. The phytosterols [179] that regulate liver cholesterol metabolism are critical to prevent and reverse NAFLD with HDL cholesterol metabolism closely linked to phytosterol ingestion [179]. Specific polyphenols found in vegetables and fruits need careful evaluation since high doses [188] [189] may cause increased oxidative stress with toxicity to the liver and induction of NAFLD and chronic disease. PXR and its role in liver regeneration [190], glucose/lipid metabolism and diets that activate PXR in the liver and periphery have become important to the prevention of NAFLD and obesity. Nutritional and therapeutic interests in pyruvic acid consumption ( 6 - $44 \mathrm{~g}$ /day) have extended to leucine metabolism in man with conversion of pyruvic acid to leucine in plants but not in man.

Leucine administration (Figure 3) has been shown to stimulate insulin release [191] [192] increase adiponectin levels and reduce cholesterol levels in rats and glucose levels in obese mice [193]-[195]. Interest in leucine administration in man has increased with the effects of leucine on food intake and appetite control that involves the hypothalamus [196] [197]. Furthermore, leucine activation of the mTOR pathway [198] that is linked to growth and disease [199] may involve the GPCR leucine rich repeats in obesity [200] [201] with leucine effects regulated by Sirt1's involvement in the inhibition of mTOR [202] [203]. The rapid metabolism of leucine in man with exercise [204]-[208] has become important to the induction of obesity with the essential role of leucine in the prevention of NAFLD. Sirt1 downregulation has been shown to be associated with skeletal muscle insulin resistance [209]-[212] with the essentiality of pyruvic acid and leucine, isoleucine and valine in the maintenance and growth of muscles (skeletal and cardiac) and metabolism of obese tissue lipids.

Furthermore, the SCN controls the circadian oscillators in peripheral tissues with leucine zipper transcription factors closely involved in xenobiotic metabolism and circadian rhythms [213] [214]. Diets high in fat have been shown to disrupt the circadian rhythms (SCN) and override leucine control of Sirt1/PXR interactions in the liver. Under fasting and exercise conditions, the high rate of leucine oxidation was found with leucine supplementation to be essential for obese individuals involved in exercise regimes for the reversal of xenobiotic toxicity in obesity [14]. Importance of dietary fibre in xenobiotic toxicity and metabolism has been reported [215] [216] 


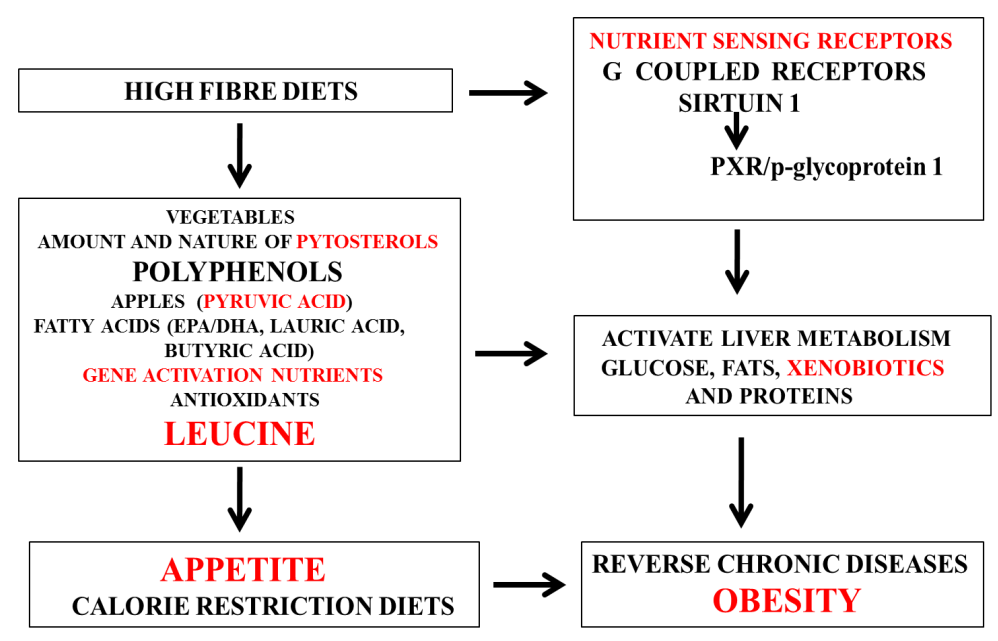

Figure 3. Nutritional interventions that target NAFLD prevent the induction of obesity.

with therapeutic leucine levels to maintain circadian control of liver glucose and insulin levels with the prevention of NAFLD and induction of obesity that is reversible in the early stages of morbid obesity but irreversible in diabetes associated with severe SCN disorders [217]. Furthermore, alterations in circadian imbalances in obesity that affect liver and kidney xenobiotic metabolism may be related to eye diseases associated with photodamage and age-related light damage of the retina by xenobiotics [218] [219].

\section{Conclusion}

There has been a rise in obesity worldwide over the past decades with an increase in obesity in both developed and developing countries. The complications of obesity are expected to rise and affect approx. $42 \%$ of the global population by the year 2030. The serious health problems include the diseases of the kidney, liver, pancreas, muscle, heart, eyes, gall bladder and brain. Several factors may be involved in the induction of obesity and include high fat/sugar diets, genetic predisposition, xenobiotic consumption, sleep deprivation, duration of drug exposure and various environmental factors such as behaviour and lifestyle that disrupt the SCN regulation of the endocrine and metabolic rhythms. Hepatic nutrient sensing nuclear receptor Sirt1 expression is dysregulated in obesity and may account for the global induction of obesity and various chronic diseases worldwide. The use of anti-obese drugs has been assessed in obesity with anti-obesity drug therapy involved in the induction of obesity and chronic disease. Diseases of the liver such as NAFLD and chronic kidney disease in obesity delay the metabolism of EDCs or POP that are closely linked to endocrine abnormalities, appetite dysregulation, cardiovascular disease, eye disease and neurodegeneration. The global health warnings have recommended various nutritional interventions with the consumption of high fibre diets that contain various food components such as pyruvic acid and leucine that may activate liver nuclear receptors (SIRT1/PXR) and reverse NAFLD with improvements in hepatic glucose, cholesterol and xenobiotic metabolism that are risk factors for disrupted SCN function that promote endocrine abnormalities in obesity and associated chronic diseases.

\section{References}

[1] James, P.T., Rigby, N. and Leach, R. (2004) The Obesity Epidemic, Metabolic Syndrome and Future Prevention Strategies. European Journal of Preventive Cardiology, 11, 3-8. http://dx.doi.org/10.1097/01.hjr.0000114707.27531.48

[2] Caballero, B. (2007) The Global Epidemic of Obesity: An Overview. Epidemiologic Reviews, 29, 1-5. http://dx.doi.org/10.1093/epirev/mxm012

[3] Katzmarzyk, P.T., Church, T.S., Janssen, I., Ross, R. and Blair, S.N. (2005) Metabolic Syndrome, Obesity, and Mortality: Impact of Cardiorespiratory Fitness. Diabetes Care, 28, 391-397. http://dx.doi.org/10.2337/diacare.28.2.391

[4] Rennie, K.L. and Jebb, S.A. (2005) Prevalence of Obesity in Great Britain. Obesity Reveiws, 6, 11-12. http://dx.doi.org/10.1111/j.1467-789X.2005.00164.X

[5] de la Monte, S.M., Longato, L., Tong, M. and Wands, J.R. (2009) Insulin Resistance and Neurodegeneration: Roles of 
Obesity, Type 2 Diabetes Mellitus and Non-Alcoholic Steatohepatitis. Current Opinion in Investigational Drugs, 10, 1049-1060.

[6] Fabbrini, E., Sullivan, S. and Klein, S. (2010) Obesity and Nonalcoholic Fatty Liver Disease: Biochemical, Metabolic, and Clinical Implications. Hepatology, 51, 679-689. http://dx.doi.org/10.1002/hep.23280

[7] Bleich, S.N., Cutler, D., Murray, C. and Adams, A. (2008) Why Is the Developed World Obese? Annual Review of Public Health, 29, 273-295. http://dx.doi.org/10.1146/annurev.publhealth.29.020907.090954

[8] Lavie, C.J., Mehra, M.R. and Milani, R.V. (2005) Obesity and Heart Failure Prognosis: Paradox or Reverse Epidemiology? European Heart Journal, 26, 5-7. http://dx.doi.org/10.1093/eurheartj/ehi055

[9] Mathew, B., Francis, L., Kayalar, A. and Cone, J. (2008) Obesity: Effects on Cardiovascular Disease and Its Diagnosis. Journal of the American Board of Family Medicine, 21, 562-568. http://dx.doi.org/10.3122/jabfm.2008.06.080080

[10] Martins, I.J., Creegan, R., Lim, W.L.F. and Martins, R.N. (2013) Molecular Insights into Appetite Control and Neuroendocrine Disease as Risk Factors for Chronic Diseases in Western Countries. Special Issue. Molecular Mechanisms Involved in Inflammation and Insulin Resistance in Chronic Diseases and Possible Interventions. Open Journal of Endocrine and Metabolic Diseases, 3, 11-33.

[11] Brody, J. (2002) The Global Epidemic of Childhood Obesity: Poverty, Urbanization, and the Nutrition Transition. Nutrition Bytes, 8, 1-7.

[12] Roberts, E.A. (2005) Non-Alcoholic Fatty Liver Disease (NAFLD) in Children. Frontiers in Bioscience, 10, 23062318. http://dx.doi.org/10.2741/1699

[13] Vos, M.B. and McClain, C.J. (2008) Nutrition and Nonalcoholic Fatty Liver Disease in Children. Current Diabetes Reports, 8, 399-406. http://dx.doi.org/10.1007/s11892-008-0069-z

[14] Martins, I.J. (2013) Increased Risk for Obesity and Diabetes with Neurodegeneration in Developing Countries. Journal of Molecular and Genetic Medicine, S1, 001.

[15] Pearce, E.N. (2012) Thyroid Hormone and Obesity. Current Opinion in Endocrinology, Diabetes \& Obesity, 19, 408413. http://dx.doi.org/10.1097/MED.0b013e328355cd6c

[16] Reinehr, T. (2010) Obesity and Thyroid Function. Molecular and Cellular Endocrinology, 316, 165-171. http://dx.doi.org/10.1016/j.mce.2009.06.005

[17] Biondi, B. (2010) Thyroid and Obesity: An Intriguing Relationship. Journal of Clinical Endocrinology \& Metabolism, 95, 3614-3617. http://dx.doi.org/10.1210/jc.2010-1245

[18] Poulain, M., Doucet, M., Major, G.C., Drapeau, V., Sériès, F., Boulet, L.P., Tremblay, A. and Maltais, F. (2006) The Effect of Obesity on Chronic Respiratory Diseases: Pathophysiology and Therapeutic Strategies. Canadian Medical Association Journal, 174, 1293-1299. http://dx.doi.org/10.1503/cmaj.051299

[19] Salome, C.N., King, G.G. and Berend, N. (2010) Physiology of Obesity and Effects on Lung Function. Journal of Applied Physiology, 108, 206-211. http://dx.doi.org/10.1152/japplphysiol.00694.2009

[20] Mietwally, M., Ledger, W.L. and Li, T.C. (2008) Reproductive Endocrinology and Clinical Aspects of Obesity in Women. Annals of the New York Academy of Sciences, 1127, 140-146. http://dx.doi.org/10.1196/annals.1434.000

[21] Martínez, J., et al. (2004) Is Obesity a Risk Factor in Acute Pancreatitis? A Meta-Analysis. Pancreatology, 4, $42-48$. http://dx.doi.org/10.1159/000077025

[22] Veeraish, C., Vaid, M., Chauhan, N. and Parashar, A. (2012) The Obesity Epidemic and Kidney Disease: A Literature Review. In: Sahay, M., Ed., Diseases of Renal Parenchyma, Chapter 4, 1-56.

http://www.intechopen.com/books/diseases-of-renal-parenchyma/theobesity-epidemic-and-kidney-disease-a-literaturereview

[23] Abrass, C.K. (2004) Overview: Obesity: What Does It Have to Do with Kidney Disease? Journal of the American Society of Nephrology, 15, 2768-2772. http://dx.doi.org/10.1097/01.ASN.0000141963.04540.3E

[24] Wells, J.C., Marphatia, A.A., Cole, T.J. and McCoy, D. (2012) Associations of Economic and Gender Inequality with Global Obesity Prevalence: Understanding the Female Excess. Social Science \& Medicine, 75, 482-490. http://dx.doi.org/10.1016/j.socscimed.2012.03.029

[25] Winter, Y., Rohrmann, S., Linseisen, J., Lanczik, O., Ringleb, P.A., Hebebrand, J. and Back, T. (2008) Contribution of Obesity and Abdominal Fat Mass to Risk of Stroke and Transient Ischemic Attacks. Stroke, 39, 3145-3151. http://dx.doi.org/10.1161/STROKEAHA.108.523001

[26] Pannacciulli, N., Del Parigi, A., Chen, K.W., Le, D.S.N.T., Reiman, E.M. and Tataranni, P.A. (2006) Brain Abnormalities in Human Obesity: A Voxel-Based Morphometric Study. NeuroImage, 31, 1419-1425. http://dx.doi.org/10.1016/j.neuroimage.2006.01.047

[27] Raji, C.A., Ho, A.J., Parikshak, N.N., Becker, J.T., Lopez, O.L., Kuller, L.H., Hua, X., Leow, A.D., Toga, A.W. and Thompson, P.M. (2010) Brain Structure and Obesity. Human Brain Mapping, 31, 353-364. 
[28] Yau, P.L., Castro, M.G., Tagani, A., Tsui, W.H. and Convit, A. (2012) Obesity and Metabolic Syndrome and Functional and Structural Brain Impairments in Adolescence. Pediatrics, 130, e856-864. http://dx.doi.org/10.1542/peds.2012-0324

[29] Whitmer, R.A., Gunderson, E.P., Barrett-Connor, E., Quesenberry Jr., C.P. and Yaffe, K. (2005) Obesity in Middle Age and Future Risk of Dementia: A 27 Year Longitudinal Population Based Study. British Medical Journal, 330, 1360. http://dx.doi.org/10.1136/bmj.38446.466238.E0

[30] Froy, O. (2010) Metabolism and Circadian Rhythms-Implications for Obesity. Endocrine Reviews, 31, 1-24. http://dx.doi.org/10.1210/er.2009-0014

[31] Mendoza, J. and Challet, E. (2009) Brain Clocks: From the Suprachiasmatic Nuclei to a Cerebral Network. The Neuroscientist, 15, 477-488.

[32] Saper, C.B., Lu, J., Chou, T.C. and Gooley, J. (2005) The Hypothalamic Integrator for Circadian Rhythms. Trends in Neurosciences, 28, 152-157. http://dx.doi.org/10.1016/j.tins.2004.12.009

[33] Yildiz, B.O., Suchard, M.A., Wong, M.L., McCann, S.M. and Licinio, J. (2004) Alteration in the Dynamics of Circulating Ghrelin, Adiponectin and Leptin in Human Obesity. Proceedings of the National Academy of Sciences of the United States of America, 101, 10434-10439. http://dx.doi.org/10.1073/pnas.0403465101

[34] Kalra, S.P., Bagnasco, M., Otukonyong, E.E., Dube, M.G. and Kalra, P.S. (2003) Rhythmic, Reciprocal Ghrelin and Leptin Signaling: New Insight in the Development of Obesity. Regulatory Peptides, 111, 1-11. http://dx.doi.org/10.1016/S0167-0115(02)00305-1

[35] Kalsbeek, A., Fliers, E., Romijn, J.A., la Fleur, S.E., Wortel, J., Bakker, O., Endert, E. and Buijs, R.M. (2001) The Suprachiasmatic Nucleus Generates the Diurnal Changes in Plasma Leptin Levels. Endocrinology, 142, 2677-2685. http://dx.doi.org/10.1210/endo.142.6.8197

[36] Horvath, T.L., Castañeda, T., Tang-Christensen, M., Pagotto, U. and Tschöp, M.H. (2003) Ghrelin as a Potential AntiObesity Target. Current Pharmaceutical Design, 9, 1383-1395. http://dx.doi.org/10.2174/1381612033454748

[37] Escobar, C., et al. (2009) Peripheral Oscillators: the Driving Force for Food-Anticipatory Activity. European Journal of Neuroscience, 30, 1665-1675. http://dx.doi.org/10.1111/j.1460-9568.2009.06972.x

[38] Russcher, M., Koch, B., Nagtegaal, E., van der Putten, K., ter Wee, P. and Gaillard, C. (2012) The Role of Melatonin Treatment in Chronic Kidney Disease. Frontiers in Bioscience (Landmark Edition), 17, 2644-2656. http://dx.doi.org/10.2741/4075

[39] Wu, L. and Reddy, A.B. (2013) Disrupting Rhythms: Diet-Induced Obesity Impairs Diurnal Rhythms in Metabolic Tissues. Diabetes, 62, 1829-1830. http://dx.doi.org/10.2337/db13-0353

[40] Bray, M.S. and Young, M.E. (2007) Circadian Rhythms in the Development of Obesity: Potential Role for the Circadian Clock within the Adipocyte. Obesity Reviews, 8, 169-181. http://dx.doi.org/10.1111/j.1467-789X.2006.00277.x

[41] Monti, J.M., Torterolo, P. and Lagos, P. (2013) Melanin-Concentrating Hormone Control of Sleep-Wake Behaviour. Sleep Medicine Reviews, 17, 293-298. http://dx.doi.org/10.1016/j.smrv.2012.10.002

[42] Lerchl, A. and Reiter, R.J. (2012) Treatment of Sleep Disorders with Melatonin. British Medical Journal, 345 , e6968. http://dx.doi.org/10.1136/bmj.e6968

[43] Gillette, M.U. and McArthur, A.J. (1996) Circadian Actions of Melatonin at the Suprachiasmatic Nucleus. Behavioural Brain Research, 73, 135-139.

[44] Cizza, G., Skarulis, M. and Mignot, E. (2005) A Link Between Short Sleep and Obesity: Building the Evidence for Causation. Sleep, 28, 1217-1220.

[45] Gangswisch, J.E., Malaspina, D., Boden-Albala, B. and Heymsfield, S.B. (2005) Inadequate Sleep as a Risk Factor for Obesity: Analysis of the NHANES I. Sleep, 28, 1289-1296.

[46] Gimble, J.M., Bray, M.S. and Young, A. (2009) Circadian Biology and Sleep: Missing Links in Obesity and Metabolism? Obesity Reviews, 10, 1-5.

[47] Reiter, R.J., Tan, D.X., Korkmaz, A. and Ma, S. (2011) Obesity and Metabolic Syndrome: Association with Chronodisruption, Sleep Deprivation, and Melatonin Suppression. Annals of Medicine, 44, 564-577.

[48] Taheri, S., Lin, L., Austin, D., Young, T. and Mignot, E. (2004) Short Sleep Duration Is Associated with Reduced Leptin, Elevated Ghrelin, and Increased Body Mass Index. PLoS Medicine, 1, e62. http://dx.doi.org/10.1371/journal.pmed.0010062

[49] Lyon, H.N. and Hirschhorn, J.N. (2005) Genetics of Common Forms of Obesity: A Brief Overview. American Journal of Clinical Nutrition, 82, 215S-217S.

[50] Walley, A.J., Blakemore, A.I.F. and Froguel, P. (2006) Genetics of Obesity and the Prediction of Risk for Health. Human Molecular Genetics, 15, R124-R130.

[51] Mutch, D.M. and Clément, K. (2006) Unraveling the Genetics of Human Obesity. PLoS Genetics, 2, e188. 
http://dx.doi.org/10.1371/journal.pgen.0020188

[52] Choi, S.W. and Friso, S. (2010) Epigenetics: A New Bridge between Nutrition and Health. Advances in Nutrition, 1, 816. http://dx.doi.org/10.3945/an.110.1004

[53] Samaras, T. and Elrick, H. (2005) An Alternative Hypothesis to the Obesity Epidemic: Obesity Is Due to Increased Maternal Body Size, Birth Size, Growth Rate, and Height. Medical Hypotheses, 65, 676-682. http://dx.doi.org/10.1016/j.mehy.2005.05.015

[54] Guarente, L. (2007) Sirtuins in Aging and Disease. Cold Spring Harbour Symposium Quantitative Biology, 72, 483488.

[55] Hansen, M.K. and Connolly, T.M. (2008) Nuclear Receptors as Drug Targets in Obesity, Dyslipidemia and Atherosclerosis. Current Opinion in Investigational Drugs, 9, 247-255.

[56] Harrison, C. (2012) Neurodegenerative Disorders: A Neuroprotective Role for Sirtuin 1. Nature Reviews Drug Discovery, 11, 108. http://dx.doi.org/10.1038/nrd3672

[57] Kawada, T., Goto, T., Hirai, S., Kang, M.S., Uemura, T., Yu, R. and Takahashi, N. (2008) Dietary Regulation of Nuclear Receptors in Obesity-Related Metabolic Syndrome. Asia Pacific Journal of Clinical Nutrition, 17, 126-130.

[58] Swanson, H.I., Wada, T., Xie, W., Renga, B., Zampella, A., Distrutti, E., Fiorucci, S., Kong, B., Thomas, A.M., Guo, G.L., Narayanan, R., Yepuru, M., Dalton, J.T. and Chiang, J.Y.L. (2013) Role of Nuclear Receptors in Lipid Dysfunction and Obesity-Related Diseases. Drug Metabolism \& Disposition, 41, 1-11. http://dx.doi.org/10.1124/dmd.112.048694

[59] Cakir, I., Perello, M., Lansari, O., Messier, N.J., Vaslet, C.A. and Nillni, E.A. (2009) Hypothalamic Sirt1 Regulates Food Intake in a Rodent Model System. PLoS ONE, 4, e8322. http://dx.doi.org/10.1371/journal.pone.0008322

[60] Kitamura, T. and Sasaki, T. (2012) Hypothalamic Sirt1 and Regulation of Food Intake. Diabetology International, 3, 109-112. http://dx.doi.org/10.1007/s13340-012-0088-5

[61] Dietrich, M.O., Antunes, C., Geliang, G., Liu, Z.W., Borok, E., Nie, Y.Z., Xu, A.W., Souza, D.O., Gao, Q., Diano, S., Gao, X.B. and Horvath, T.L. (2010) Agrp Neurons Mediate Sirt1's Action on the Melanocortin System and Energy Balance: Roles for Sirt1 in Neuronal Firing and Synaptic Plasticity. Journal of Neuroscience, 30, 11815-11825. http://dx.doi.org/10.1523/JNEUROSCI.2234-10.2010

[62] Schaffhauser, A.O., Madiehe, A.M., Braymer, H.D., Bray, G.A. and York, D.A. (2002) Effects of a High-Fat Diet and Strain on Hypothalamic Gene Expression in Rats. Obesity Research, 10, 1188-1196. http://dx.doi.org/10.1038/oby.2002.161

[63] Lee, A.K., Mojtahed-Jaberi, M., Kyriakou, T., Astarloa, E.A.O., Arno, M., Marshall, N.J., Brain, S.D. and O’Dell, S.D. (2010) Effect of High-Fat Feeding on Expression of Genes Controlling Availability of Dopamine in Mouse Hypothalamus. Nutrition, 26, 411-422. http://dx.doi.org/10.1016/j.nut.2009.05.007

[64] Garaulet, M., Esteban Tardido, A., Lee, Y.C., Smith, C.E., Parnell, L.D. and Ordovás, J.M. (2012) SIRT1 and CLOCK $3111 \mathrm{~T}>\mathrm{C}$ Combined Genotype Is Associated with Evening Preference and Weight Loss Resistance in a Behavioral Therapy Treatment for Obesity. International Journal of Obesity, 36, 1436-1441.

[65] Shimoyama, Y., Suzuki, K., Hamajima, N. and Niwa, T. (2011) Sirtuin 1 Gene Polymorphisms Are Associated with Body Fat and Blood Pressure in Japanese. Translational Research, 157, 339-347. http://dx.doi.org/10.1016/j.trsl.2011.02.004

[66] Shimoyama, Y., Mitsuda, Y., Tsuruta, Y., Suzuki, K., Hamajima, N. and Niwa, T. (2012) SIRTUIN 1 Gene Polymorphisms Are Associated with Cholesterol Metabolism and Coronary Artery Calcification in Japanese Hemodialysis Patients. Journal of Renal Nutrition, 22, 114-119. http://dx.doi.org/10.1053/i.jrn.2011.10.025

[67] Clark, S.J., Falchi, M., Olsson, B., et al. (2012) Association of Sirtuin 1 (SIRT1) Gene SNPs and Transcript Expression Levels with Severe Obesity. Obesity (Silver Spring), 20, 178-185. http://dx.doi.org/10.1038/oby.2011.200

[68] Flachsbart, F., Croucher, P.J.P., Nikolaus, S., Hampe, J., Cordes, C., Schreiber, S. and Nebela, A. (2006) Sirtuin 1 (SIRT1) Sequence Variation Is Not Associated with Exceptional Human Longevity. Experimental Gerontology, 41, 98-102. http://dx.doi.org/10.1016/j.exger.2005.09.008

[69] Cohen, D.E., Supinski, A.M., Bonkowski, M.S., Donmez, G. and Guarente, L.P. (2009) Neuronal SIRT1 Regulates Endocrine and Behavioral Responses to Calorie Restriction. Genes \& Development, 23, 2812-2817.

[70] Moore, R.L. and Faller, D.V. (2013) SIRT1 Represses Estrogen-Signaling, Ligand-Independent ER $\alpha$-Mediated Transcription, and Cell Proliferation in Estrogen-Responsive Breast Cells. Journal of Endocrinology, 216, 273-285. http://dx.doi.org/10.1530/JOE-12-0102

[71] Liang F, Kume S, Koya D, Kume, S. and Daisuke, K. (2009) SIRT1 and Insulin Resistance. Nature Reviews. Endocrinology, 5, 367-373.

[72] Takano, A., Haruta, T., Iwata, M., Usui, I., Uno, T., Kawahara, J., Ueno, E., Sasaoka, T. and Kobayashi, M. (2001) 
Growth Hormone Induces Cellular Insulin Resistance by Uncoupling Phosphatidylinositol 3-Kinase and Its Downstream Signals in 3T3-L1 Adipocytes. Diabetes, 50, 1891-1900. http://dx.doi.org/10.2337/diabetes.50.8.1891

[73] Kitada, M., Kume, S., Takeda-Watanabe, A., Kanasaki, K. and Koya, D. (2013) Sirtuins and Renal Diseases: Relationship with Aging and Diabetic Nephropathy. Clinical Science, 124, 153-164. http://dx.doi.org/10.1042/CS20120190

[74] Rajendrasozhan, S., Yang, S.R., Kinnula, V.L. and Rahman, I. (2008) SIRT1, an Antiinflammatory and Antiaging Protein, Is Decreased in Lungs of Patients with Chronic Obstructive Pulmonary Disease. American Journal Respiration Critical Care Medicine, 177, 861-870. http://dx.doi.org/10.1164/rccm.200708-1269OC

[75] Archer, R. and Baker, E.H. (2009) Diabetes and Metabolic Dysfunction in COPD. Respiratory Medicine, 5, 67-74.

[76] Kang, J.E., Lim, M.M., Bateman, R.J., Lee, J.J., Smyth, L.P., Cirrito, J.R., Fujiki, N., Nishino, S. and Holtzman, D.M. (2009) Amyloid-Beta Dynamics Are Regulated by Orexin and the Sleep-Wake Cycle. Science, 326, 1005-1007.

[77] Xie, H., Sun, L. and Lodish, H.F. (2009) Targeting MicroRNAs in Obesity. Expert Opinion on Therapeutic Targets, 13, 1227-1238. http://dx.doi.org/10.1517/14728220903190707

[78] Huangming, X., Lim, B. and Lodish, H.F. (2009) MicroRNAs Induced during Adipogenesis that Accelerate Fat Cell Development Are Downregulated in Obesity. Diabetes, 58, 1050-1057. http://dx.doi.org/10.2337/db08-1299

[79] McGregor, R.A. and Choi, M.S. (2011) microRNAs in the Regulation of Adipogenesis and Obesity. Current Molecular Medicine, 11, 304-316. http://dx.doi.org/10.2174/156652411795677990

[80] Lee, J. and Kemper, J.K. (2010) Controlling SIRT1 Expression by microRNAs in Health and Metabolic Disease. Aging (Albany NY), 2, 527-534.

[81] Tsai, K.L., Chen, L.H., Chen, Y.C., Kao, C.L., Chen, L.K. and Chiou, S.H. (2011) The Role of microRNAs in Modulating Sirtuin 1 Expression. Journal of Clinical Gerontology and Geriatrics, 2, 71-75. http://dx.doi.org/10.1016/j.jcgg.2011.06.004

[82] Christine, P., Cambridge, E.L., Lelliott, C.J., Carragher, D.M., Estabel, J., Gerdin, A.K., Karp, N.A., Scudamore, C.L., Ramirez-Solis, R. and White, J.K. (2013) High-Fat Feeding Rapidly Induces Obesity and Lipid Derangements in C57BL/6N Mice. Mammalian Genome, 24, 240-251. http://dx.doi.org/10.1007/s00335-013-9456-0

[83] Hsuchou, H., He, Y., Kastin, A.J., Tu, H., Markadakis, E.N., Rogers, R.C., Fossier, P.B. and Pan, W.H. (2009) Obesity Induces Functional Astrocytic Leptin Receptors in Hypothalamus. Brain, 132, 889-902.

[84] Bunyan, J., Murell, E.A. and Shah, P.P. (1976) The Induction of Obesity in Rodents by Means of Monosodium Glutamate. British Journal of Nutrition, 35, 25-39.

[85] Wang, C.Y. and Liao, J.K. (2012) A Mouse Model of Diet-Induced Obesity and Insulin Resistance. Methods in Molecular Biology, 821, 421-433. http://dx.doi.org/10.1007/978-1-61779-430-8_27

[86] Lin, S., Thomas, T.C., Storlien, L.H. and Huang, X.F. (2000) Development of High Fat Diet-Induced Obesity and Leptin Resistance in C57B1/6J Mice. International Journal of Obesity, 24, 639-646. http://dx.doi.org/10.1038/sj.ijo.0801209

[87] Peng, Y., Rideout, D., Rakita, S., Lee, J. and Murr, M. (2012) Diet-Induced Obesity Associated with Steatosis, Oxidative Stress, and Inflammation in Liver. Surgical for Obesity and Related Diseases, 8, 73-81. http://dx.doi.org/10.1016/j.soard.2011.07.019

[88] Anstee, Q.M. and Goldin, R.D. (2006) Mouse Models in Non-Alcoholic Fatty Liver Disease and Steatohepatitis Research. International Journal of Experimental Pathology, 87, 1-16. http://dx.doi.org/10.1111/j.0959-9673.2006.00465.x

[89] Browning, J.D. and Horton, J.D. (2004) Molecular Mediators of Hepatic Steatosis and Liver Injury. Journal of Clinical Investigation, 114, 147-152. http://dx.doi.org/10.1172/JCI200422422

[90] Qatanani, M. and Lazar, M.A. (2007) Mechanisms of Obesity-Associated Insulin Resistance: Many Choices on the Menu. Genes \& Development, 21, 1443-1455. http://dx.doi.org/10.1101/gad.1550907

[91] Martins, I.J. and Redgrave, T.G. (2004) Obesity and Post-Prandial Lipid Metabolism. Feast or Famine? Journal of Nutritional Biochemistry, 15, 130-141. http://dx.doi.org/10.1016/i.jnutbio.2003.10.006

[92] Martins, I.J., Tran, J.M. and Redgrave, T.G. (2002) Food Restriction Normalizes Chylomicron Remnant Metabolism in Murine Models of Obesity as Assessed by a Novel Stable Isotope Breath Test. Journal of Nutrition, 132, 176-181.

[93] Martins, I.J., Sainsbury, A.J., Mamo, J.C. and Redgrave, T.G. (1994) Lipid and Apolipoprotein B48 Transport in Mesenteric Lymph and the Effect of Hyperphagia on the Clearance of Chylomicron-Like Emulsions in Insulin-Deficient Rats. Diabetologia, 37, 238-246. http://dx.doi.org/10.1007/BF00398049

[94] Dane-Stewart, C.A., Watts, G.F., Barrett, P.H.R., Stuckey, B.G.A., Mamo, J.C.L., Martins, I.J. and Redgrave, T.G. (2003) Chylomicron Remnant Metabolism Studied with a New Breath Test in Postmenopausal Women with and without Type 2 Diabetes Mellitus. Clinical Endocrinology, 58, 415-420.

http://dx.doi.org/10.1046/j.1365-2265.2003.01731.x 
[95] Watts, G.F., Chan, D.C.F., Barrett, P.H.R., Martins, I.J. and Redgrave, T.G. (2001) Preliminary Experience with a New Stable Isotope Breath Test for Chylomicron Remnant Metabolism: A Study in Central Obesity. Clinical Science, 101, 683-690. http://dx.doi.org/10.1042/CS20010166

[96] Chan, D.C., Watts, G.F., Barrett, P.H., Martins, I.J., James, A.P., Mamo, J.C., Mori, T.A. and Redgrave, T.G. (2002) Effect of Atorvastatin on Chylomicron Remnant Metabolism in Visceral Obesity: A Study Employing a New Stable Isotope Breath Test. Journal of Lipid Research, 43, 706-712.

[97] Martins, I.J., Mortimer, B.C., Miller, J. and Redgrave, T.G. (1996) Effects of Particle Size and Number on the Plasma Clearance of Chylomicrons and Remnants. Journal of Lipid Research, 37, 2696-2705.

[98] Casals-Casas, C. and Desvergne, B. (2011) Endocrine Disruptors: From Endocrine to Metabolic Disruption. Annual Review of Physiology, 73, 135-162. http://dx.doi.org/10.1146/annurev-physiol-012110-142200

[99] Grün, F. and Blumberg, B. (2009) Endocrine Disrupters as Obesogens. Molecular and Cellular Endocrinology, 304, 19-29. http://dx.doi.org/10.1016/j.mce.2009.02.018

[100] Polyzos, S.A., Kountouras, J., Deretzi, G., Zavos, C. and Mantzoros, C.S. (2012) The Emerging Role of Endocrine Disruptors in Pathogenesis of Insulin Resistance: A Concept Implicating Nonalcoholic Fatty Liver Disease. Current Molecular Medicine, 12, 68-82. http://dx.doi.org/10.2174/156652412798376161

[101] Elobeid, M.A. and Alison, D.B. (2008) Putative Environmental-Endocrine Disruptors and Obesity: A Review. Current Opinion in Endocrinology, Diabetes \& Obesity, 15, 403-408. http://dx.doi.org/10.1097/MED.0b013e32830ce95c

[102] Arciello, M., Gori, M., Maggio, R., Barbaro, B., Tarocchi, M., Galli, A. and Balsano, C. (2013) Environmental Pollution: A Tangible Risk for NAFLD Pathogenesis. International Journal of Molecular Sciences, 14, 22052-22066. http://dx.doi.org/10.3390/ijms141122052

[103] Yu, W., Laseter, J. and Mylander, C. (2011) Persistent Organic Pollutants in Serum and Several Different Fat Compartments in Humans. Journal of Environmental and Public Health, 2011, Article ID: 417980, 8 pages.

[104] Schug, T.T., Janesick, A., Blumberg, B. and Heindel, J.J. (2011) Endocrine Disrupting Chemicals and Disease Susceptibility. Journal Steroid Biochemistry Molecular Biology, 127, 204-215. http://dx.doi.org/10.1016/j.jsbmb.2011.08.007

[105] Jarrett, R.E. (2000) Endocrine Disruptor Chemicals as a Rising Compliance Issue. Federal Facilities Environmental Journal, 11, 25-39. http://dx.doi.org/10.1002/ffej.3330110104

[106] Manning, T. (2005) Endocrine-Disrupting Chemicals: A Review of the State of the Science. Australasian Journal of Ecotoxicology, Endocrine Disrupting Chemicals Review, 11, 1-52

[107] Martins, I.J., Lim, W.L.F., Wilson, A.C., Laws, S.M. and Martins, R.N. (2013) The Acceleration of Aging and Alzheimer's Disease through the Biological Mechanisms behind Obesity and Type II Diabetes. Health, 5, 913-920. http://dx.doi.org/10.4236/health.2013.55121

[108] Martins, I.J., Wilson, A.C., Lim, W.L.F., Laws, S.M., Fuller, S.J. and Martins, R.N. (2012) Sirtuin-1 Mediates the Obesity Induced Risk of Common Degenerative Diseases: Alzheimer's Disease, Coronary Artery Disease and Type 2 Diabetes. Health, 4, 1448-1456. http://dx.doi.org/10.4236/health.2012.412A209

[109] Salminen, A., Kaarniranta, K. and Kauppinen, A. (2013) Crosstalk between Oxidative Stress and SIRT1: Impact on the Aging Process. International Journal of Molecular Sciences, 14, 3834-3859. http://dx.doi.org/10.3390/ijms14023834

[110] Caito, S., Rajendrasozhan, S., Cook, S., Chung, S., Yao, H.W., Friedman, A.E., Brookes, P.S. and Rahman, I. (2010) SIRT1 Is a Redox-Sensitive Deacetylase that Is Post-Translationally Modified by Oxidants and Carbonyl Stress. FASEB Journal, 24, 3145-3159. http://dx.doi.org/10.1096/fj.09-151308

[111] Xu, F., Gao, Z.G., Zhang, J., Rivera, C.A., Yin, J., Weng, J.P. and Ye, J.P. (2010) Lack of SIRT1 (Mammalian Sirtuin 1) Activity Leads to Liver Steatosis in the SIRT1+/-Mice: A Role of Lipid Mobilization and Inflammation. Endocrinology, 151, 2504-2514. http://dx.doi.org/10.1210/en.2009-1013

[112] Purushotham, A., Xu, Q. and Li, X.L. (2012) Systemic SIRT1 Insufficiency Results in Disruption of Energy Homeostasis and Steroid Hormone Metabolism upon High-Fat-Diet Feeding. FASEB Journal, 26, 656-667. http://dx.doi.org/10.1096/fj.11-195172

[113] Bordone, L., Cohen, D., Robinson, A., Motta, M.C., Van Veen, E., Czopik, A., Steele, A.D., Crowe, H., Marmor, S., Luo, J.Y., Gu, W. and Guarente, L. (2007) SIRT1 Transgenic Mice Show Phenotypes Resembling Calorie Restriction. Aging Cell, 6, 759-767. http://dx.doi.org/10.1111/j.1474-9726.2007.00335.x

[114] Hao, C., Cheng, X.J., Xia, H.F. and Ma, X. (2012) The Endocrine Disruptor Mono-(2-ethylhexyl) Phthalate Promotes Adipocyte Differentiation and Induces Obesity in Mice. Bioscience Reports, 32, 619-629. http://dx.doi.org/10.1042/BSR20120042

[115] Bility, M.T., Thompson, J.T., McKee, R.H., David, R.M., Butala, J.H., Vanden Heuvel, J.P. and Peters, J.M. (2004) Activation of Mouse and Human Peroxisome Proliferator-Activated Receptors (PPARs) by Phthalate Monoesters. Toxicological Sciences, 82, 170-182. http://dx.doi.org/10.1093/toxsci/kfh253 
[116] De Coster, S. and van Larebeke, N. (2012) Endocrine-Disrupting Chemicals: Associated Disorders and Mechanisms of Action. Journal of Environmental and Public Health, 2012, Article ID: 713696, 52 pages.

[117] Sun, Y., Guo, Z.K., Iku, S., Saito, T. and Kurasaki, M. (2013) Diethyl Phthalate Enhances Expression of SIRT1 and DNMT3a during Apoptosis in PC12 Cells. Journal of Applied Toxicology, 33, 1484-1492. http://dx.doi.org/10.1002/jat.2816

[118] Kambia, N., Renault, N., Dilly, S., Farce, A., Dine, T., Gressier, B., Luyckx, M., Brunet, C. and Chavatte, P. (2008) Molecular Modelling of Phthalates-PPARs Interactions. Journal of Enzyme Inhibition and Medicinal Chemistry, 23, 611-616. http://dx.doi.org/10.1080/14756360802205059

[119] Martina, C.A., Weiss, B. and Swan, S.H. (2012) Lifestyle Behaviours Associated with Exposures to Endocrine Disruptors. NeuroToxicology, 33, 1427-1433. http://dx.doi.org/10.1016/j.neuro.2012.05.016

[120] Wang, J., Lv, X.W., Shi, J.P. and Hu, X.S. (2006) Ceramide Induces Apoptosis via a Peroxisome Proliferator-Activated Receptor Gamma-Dependent Pathway. Apoptosis, 11, 2043-2052. http://dx.doi.org/10.1007/s10495-006-0191-9

[121] LeCluyse, E.L. (2001) Pregnane X Receptor: Molecular Basis for Species Differences in CYP3A Induction by Xenobiotics. Chemico-Biological Interactions, 134, 283-289. http://dx.doi.org/10.1016/S0009-2797(01)00163-6

[122] Gao, J. and Xie, W. (2010) Pregnane X Receptor and Constitutive Androstane Receptor at the Crossroads of Drug Metabolism and Energy Metabolism. Drug Metabolism \& Disposition, 38, 2091-2095. http://dx.doi.org/10.1124/dmd.110.035568

[123] Spruiell, K., Richardson, R.M., Cullen, J.M., Awumey, E.M., Gonzalez, F.J. and Gyamfi, M.A. (2014) Role of Pregnane X Receptor in Obesity and Glucose Homeostasis in Male Mice. Journal of Biological Chemistry, 289, 3244-3261. http://dx.doi.org/10.1074/jbc.M113.494575

[124] Shelness, G.S. and Rudel, L.L. (2005) A Role for the Pregnane X Receptor in High-Density Lipoprotein Metabolism. Arteriosclerosis, Thrombosis, and Vascular Biology, 25, 2016-2017. http://dx.doi.org/10.1161/01.ATV.0000186042.94668.2b

[125] Masson, D., Lagrost, L., Athias, A., Gambert, P., Brimer-Cline, C., Lan, L., Schuetz, J.D., Schuetz, E.G. and Assem, M. (2005) Expression of the Pregnane X Receptor in Mice Antagonizes the Cholic Acid-Mediated Changes in Plasma Lipoprotein Profile. Arteriosclerosis, Thrombosis, and Vascular Biology, 25, 2164-2169. http://dx.doi.org/10.1161/01.ATV.0000183674.88817.fb

[126] Hukkanen, J., Hakkola, J. and Rysa, J. (2012) Pregnane X Receptor (PXR)—A Contributor to the Diabetes Epidemic? Drug Metabolism and Drug Interactions, 29, 3-15.

[127] Neel, B.A. and Sargis, R.M. (2011) The Paradox of Progress: Environmental Disruption of Metabolism and the Diabetes Epidemic. Diabetes, 60, 1838-1848. http://dx.doi.org/10.2337/db11-0153

[128] Wingfield, J.C. and Mukai, M. (2009) Endocrine Disruption in the Context of Life Cycles: Perception and Transduction of Environmental Cues. General and Comparative Endocrinology, 163, 92-96.

[129] Zmrzljak, U.P. and Rozman, D. (2012) Circadian Regulation of the Hepatic Endobiotic and Xenobitoic Detoxification Pathways: The Time Matters. Chemical Research in Toxicology, 25, 811-824. http://dx.doi.org/10.1021/tx200538r

[130] Claudel, T., Cretenet, G., Saumet, A. and Gachon, F. (2007) Crosstalk between Xenobiotics Metabolism and Circadian Clock. FEBS Letters, 581, 3626-3633. http://dx.doi.org/10.1016/j.febslet.2007.04.009

[131] Wang, X.H., Fang, X., Zhou, J., Chen, Z., Zhao, B.L., Xiao, L., Liu, A., Li, Y.S.J., Shyy, J.Y.J., Guan, Y.F., Chien, S. and Wang, N.P. (2013) Shear Stress Activation of Nuclear Receptor PXR in Endothelial Detoxification. Proceedings of the National Academy of Sciences of the United States of America, 110, 13174-13179. http://dx.doi.org/10.1073/pnas.1312065110

[132] Wu-Wong, J.R. (2008) Endothelial Dysfunction and Chronic Kidney Disease: Treatment Options. Current Opinion in Investigational Drugs, 9, 970-982.

[133] Herrera, M.D., Mingorance, C., Rodríguez-Rodríguez, R. and de Sotomayor, M.A. (2010) Endothelial Dysfunction and Aging: An Update. Ageing Research Reviews, 9, 142-152. http://dx.doi.org/10.1016/j.arr.2009.07.002

[134] Arao, T., Takabatake, N., Sata, M., Abe, S., Shibata, Y., Honma, T., Takahashi, K., Okada, A., Takeishi, Y. and Kubota, I. (2003) In Vivo Evidence of Endothelial Injury in Chronic Obstructive Pulmonary Disease by Lung Scintigraphic Assessment of (123)I-Metaiodobenzylguanidine. Journal of Nuclear Medicine, 44, 1747-1754.

[135] Perticone, F., Ceravolo, R., Candigliota, M., Ventura, G., Iacopino, S., Sinopoli, F. and Mattioli, P.L. (2001) Obesity and Body Fat Distribution Induce Endothelial Dysfunction by Oxidative Stress: Protective Effect of Vitamin C. Diabetes, 50, 159-165. http://dx.doi.org/10.2337/diabetes.50.1.159

[136] Steinberg, H.O., Chaker, H., Leaming, R., Johnson, A., Brechtel, G. and Baron, A.D. (1996) Obesity/Insulin Resistance Is Associated with Endothelial Dysfunction. Implications for the Syndrome of Insulin Resistance. Journal of Clinical Investigation, 97, 2601-2610. http://dx.doi.org/10.1172/JCI118709 
[137] Schinkel, A.H. (1999) P-Glycoprotein, a Gatekeeper in the Blood-Brain Barrier. Advanced Drug Delivery Reviews, 36, 179-194. http://dx.doi.org/10.1016/S0169-409X(98)00085-4

[138] Garrigues, A., Escargueil, A.E. and Orlowski, S. (2002) The Multidrug Transporter, P-Glycoprotein, Actively Mediates Cholesterol Redistribution in the Cell Membrane. Proceedings of the National Academy of Sciences of the United States of America, 99, 10347-10352. http://dx.doi.org/10.1073/pnas.162366399

[139] Le Goff, W., Settle, M., Greene, D.J., Morton, R.E. and Smith, J.D. (2006) Reevaluation of the Role of the MultidrugResistant P-Glycoprotein in Cellular Cholesterol Homeostasis. Journal of Lipid Research, 47, 51-58. http://dx.doi.org/10.1194/jlr.M500255-JLR200

[140] Wessler, J.D., Grip, L.T., Mendell, J. and Giugliano, R.P. (2013) The P-Glycoprotein Transport System and Cardiovascular Drugs. Journal of American College of Cardiology, 61, 2495-2502. http://dx.doi.org/10.1016/j.jacc.2013.02.058

[141] Wittgen, H.G., Greupink, R., van den Heuvel, J.J., van den Broek, P.H., Dinter-Heidorn, H., Koenderink, J.B. and Russel, F.G. (2012) Exploiting Transport Activity of p-Glycoprotein at the Blood-Brain Barrier for the Development of Peripheral Cannabinoid Type 1 Receptor Antagonists. Molecular Pharmaceutics, 9, 1351-1360.

[142] Foucaud-Vignault, M., Soayfane, Z., Ménez, C., Bertrand-Michel, J., Martin, P.G.P., Guillou, H., Collet, X. and Lespine, A. (2011) P-Glycoprotein Dysfunction Contributes to Hepatic Steatosis and Obesity in Mice. PLoS ONE, 6, e23614. http://dx.doi.org/10.1371/journal.pone.0023614

[143] Abuznait, A.H., Cain, C., Ingram, D., Burk, D. and Kaddoum, A. (2011) Up-Regulation of P-Glycoprotein Reduces Intracellular Accumulation of Beta Amyloid: Investigation of P-Glycoprotein as a Novel Therapeutic Target for Alzheimer's Disease. Journal of Pharmacy and Pharmacology, 63, 1111-1118. http://dx.doi.org/10.1111/j.2042-7158.2011.01309.x

[144] Lam, F.C., Liu, R.H., Lu, P.H., Shapiro, A.B., Renoir, J.M., Sharom, F.J. and Reiner, P.B. (2001) Beta-Amyloid Efflux Mediated by p-Glycoprotein. Journal of Neurochemistry, 76, 1121-1128. http://dx.doi.org/10.1046/j.1471-4159.2001.00113.x

[145] Rigalli, P., Ruiz, M.L., Perdomo, V.G., Villanueva, S.S.M., Mottino, A.D. and Catania, V.A. (2011) Pregnane X Receptor Mediates the Induction of P-Glycoprotein by Spironolactone in HepG2 Cells. Toxicology, 285, 18-24. http://dx.doi.org/10.1016/j.tox.2011.03.015

[146] Bauer, B., Hartz, A.M., Fricker, G. and Miller, D.S. (2004) Pregnane X Receptor Up-Regulation of P-Glycoprotein Expression and Transport Function at the Blood-Brain Barrier. Molecular Pharmacology, 66, 413-419.

[147] Cheng, X. and Klaassen, C.D. (2009) Tissue Distribution, Ontogeny, and Hormonal Regulation of Xenobiotic Transporters in Mouse Kidneys. Drug Metabolism \& Disposition, 37, 2178-2185. http://dx.doi.org/10.1124/dmd.109.027177

[148] Lock, E.A. and Reed. C.J. (1998) Xenobiotic Metabolizing Enzymes of the Kidney. Toxicologic Pathology, 26, 18-25. http://dx.doi.org/10.1177/019262339802600102

[149] Dember, L.N. (2006) Amyloidosis-Associated Kidney Disease. Journal of the American Society of Nephrology, 17, 3458-3471. http://dx.doi.org/10.1681/ASN.2006050460

[150] Wang, Y., Chen, X.L., Klag, M.J. and Caballero, B. (2006) Epidemic of Childhood Obesity: Implications for Kidney Disease. Advances in Chronic Kidney Disease, 13, 336-351. http://dx.doi.org/10.1053/j.ackd.2006.07.016

[151] Rodgers, J.R., Tschöp, M.H. and Wilding, J.P.H. (2012) Anti-Obesity Drugs: Past, Present and Future. Disease Models \& Mechanisms, 5, 621-626. http://dx.doi.org/10.1242/dmm.009621

[152] Hainer, V. and Hainerová, I.A. (2012) Do We Need Anti-Obesity Drugs? Diabetes/Metabolism Research and Reveiws, 28, 8-20. http://dx.doi.org/10.1002/dmrr.2349

[153] Gosden, D.J. and Smith, S.L. (2012) What Is the Prognosis for New Centrally-Acting Anti-Obesity Drugs? Neuropharmacology, 63, 132-146. http://dx.doi.org/10.1016/j.neuropharm.2012.01.017

[154] Hatahet, M.A. and Dhurandhar, N.V. (2002) Antiobesity Drugs: Current and Future Issues. Current Diabetes Reports, 2, 409-415. http://dx.doi.org/10.1007/s11892-002-0105-3

[155] Halford, J.C.G. and Blundell, J.E. (2000) Pharmacology of Appetite Suppression. Progress in Drug Research, 54, 2558. http://dx.doi.org/10.1007/978-3-0348-8391-7_2

[156] Adan, R.A.H. (2013) Mechanisms Underlying Current and Future Anti-Obesity Drugs. Trends in Neurosciences, 36, 133-140. http://dx.doi.org/10.1016/j.tins.2012.12.001

[157] Derosa, G. and Maffioli, P. (2012) Anti-Obesity Drugs: A Review about Their Effects and Their Safety. Expert Opinion on Drug Safety, 11, 459-471. http://dx.doi.org/10.1517/14740338.2012.675326

[158] Elangbam, C.S. (2009) Current Strategies in the Development of Anti-Obesity Drugs and Their Safety Concerns. Veterinary Pathology, 46, 10-24. http://dx.doi.org/10.1354/vp.46-1-10

[159] Li, M.F. and Cheung, B.M.Y. (2011) Rise and Fall of Anti-Obesity Drugs. World Journal of Diabetes, 2, 19-23. 
http://dx.doi.org/10.4239/wjd.v2.i2.19

[160] Hooft, R. (2003) Drug Discovery and Development for Metabolic Diseases. Drug Discovery Today, 8, 1064-1066. http://dx.doi.org/10.1016/S1359-6446(03)02919-2

[161] Finer, N. (2002) Pharmacotherapy of Obesity. Best Practice \& Research Clinical Endocrinology \& Metabolism, 16, 717-742.

[162] Loannides-Demos, L.L., Piccenna, L. and John, J. (2011) Pharmacotherapies for Obesity: Past, Current, and Future Therapies. Journal of Obesity, 2011, Article ID: 179674.

[163] Fong, T.M. (2008) Development of Anti-Obesity Agents: Drugs that Target Neuropeptide and Neurotransmitter Systems. Expert Opinion on Investigational Drugs, 17, 321-325. http://dx.doi.org/10.1517/13543784.17.3.321

[164] Oh, S., Kim, K.S., Chung, Y.S., Shong, M. and Park, S.B. (2009) Anti-Obesity Agents: A Focused Review on the Structural Classification of Therapeutic Entities. Current Topics in Medicinal Chemistry, 9, 466-481. http://dx.doi.org/10.2174/156802609788897862

[165] Breum, L. and Fernstrom, M.H. (2001) Drug-Induced Obesity. In: Björntorp, P. Ed., International Textbook of Obesity, Chapter 19, John Wiley \& Sons, Ltd., Chichester, 269-281.

[166] Dent, R., Blackmore, A., Peterson, J., Habib, R., Kay, G.P., Gervais, A., Taylor, V. and Wells, G. (2012) Changes in Body Weight and Psychotropic Drugs: A Systematic Synthesis of the Literature. PLoS ONE, 7, e36889. http://dx.doi.org/10.1371/journal.pone.0036889

[167] Bernstein, J.G. (1987) Induction of Obesity by Psychotropic Drugs. Annals of the New York Academy of Sciences, 499, 203-215. http://dx.doi.org/10.1111/j.1749-6632.1987.tb36212.x

[168] Schwartz, T.L., Nihalani, N., Jindal, S., Virk, S. and Jones, N. (2004) Psychiatric Medication-Induced Obesity: A Review. Obesity Reviews, 5, 115-121. http://dx.doi.org/10.1111/j.1467-789X.2004.00139.x

[169] Martins, I.J., Wood, K.M., Fernandis, A.Z., Taddei, K. and Martins, R.N. (2013) Anti-Oxidative Acylcoa Cholesterol Acyltransferase Inhibitor Avasimibe Reduces the Impact of a High Cholesterol Diet on Brain Lipid Peroxidation in Mice. $A D P D$, Florence. www.kenes.com

[170] Lai, C.S., Ho, M.H., Tsai, M.L., Li, S.M., Badmaev, V., Ho, C.T. and Pan, M.H. (2013) Suppression of Adipogenesis and Obesity in High-Fat Induced Mouse Model by Hydroxylated Polymethoxyflavones. Journal of Agricultural and Food Chemistry, 61, 10320-10328. http://dx.doi.org/10.1021/jf402257t

[171] Maeda, H., Hosokawa, M., Sashima, T., Murakami-Funayama, K. and Miyashita, K. (2009) Anti-Obesity and AntiDiabetic Effects of Fucoxanthin on Diet-Induced Obesity Conditions in a Murine Model. Molecular Medicine Reports, 2, 897-902. http://dx.doi.org/10.3892/mmr_00000189

[172] Sugatani, J., Wada, T., Osabe, M., Yamakawa, K., Yoshinari, K. and Miwa, M. (2006) Dietary Inulin Alleviates Hepatic Steatosis and Xenobiotics-Induced Liver Injury in Rats Fed a High-Fat and High-Sucrose Diet: Association with the Suppression of Hepatic Cytochrome P450 and Hepatocyte Nuclear Factor $4 \alpha$ Expression. Drug Metabolism and Disposition, 34, 1677-1687. http://dx.doi.org/10.1124/dmd.106.010645

[173] Mathur, S.J.N. (2003) Ginger and Its Role in Xenobiotic Metabolism. ICMR Bulletin, 33, 57-63.

[174] Jobu, K., Yokota, J., Yoshioka, S., Moriyama, H., Murata, S., Ohishi, M., Ukeda, H. and Miyamura, M. (2013) Effects of Goishi Tea on Diet-Induced Obesity in Mice. Food Research International, 54, 324-329. http://dx.doi.org/10.1016/j.foodres.2013.07.037

[175] Muramkami, A. (2013) Modulation of Protein Quality Control Systems by Food Phytochemicals. Journal of Clinical Biochemistry and Nutrition, 52, 215-227. http://dx.doi.org/10.3164/jcbn.12-126

[176] Imam, M.U. and Ismail, M. (2012) Effects of Brown Rice and White Rice on Expression of Xenobiotic Metabolism Genes in Type 2 Diabetic rats. International Journal of Molecular Sciences, 13, 8597-8608. http://dx.doi.org/10.3390/ijms13078597

[177] Pan, M., Song, Y.L., Xu, J.M. and Gan, H.Z. (2006) Melatonin Ameliorates Nonalcoholic Fatty Liver Induced by HighFat Diet in Rats. Journal of Pineal Research, 41, 79-84. http://dx.doi.org/10.1111/j.1600-079X.2006.00346.x

[178] Pfluger, P.T., Herranz, D., Velasco-Miguel, S., Serrano, M. and Tschop, M.H. (2008) Sirt1 Protects against High-Fat Diet-Induced Metabolic Damage. Proceedings of the National Academy of Sciences of the United States of America, 105, 9793-9798. http://dx.doi.org/10.1073/pnas.0802917105

[179] Martins, I.J. and Fernando, W.M.A.D. (2014) High Fibre Diets and Alzheimer's Disease. Food and Nutrition Sciences, 5, 410-424. http://dx.doi.org/10.4236/fns.2014.54049

[180] Buler, M., Aatsinki, S.M., Skoumal, R. and Hakkola, J. (2011) Energy Sensing Factors PGC-1 $\alpha$ and SIRT1 Modulate PXR Expression and Function. Biochemical Pharmacology, 82, 2008-2015. http://dx.doi.org/10.1016/j.bcp.2011.09.006

[181] Suchankova, G., Nelson, L.E., Gerhart-Hines, Z., Kelly, M., Gauthier, M.S., Saha, A.K., Ido, Y., Puigserver, P. and 
Ruderman, N.B. (2009) Concurrent Regulation of AMP-Activated Protein Kinase and SIRT1 in Mammalian Cells. Biochemical and Biophysical Research Communications, 378, 836-841.

http://dx.doi.org/10.1016/j.bbrc.2008.11.130

[182] Stanko, R.T., Reynolds, H.R., Hoyson, R., Janosky, J.E. and Wolf, R. (1994) Pyruvate Supplementation of a LowCholesterol, Low-Fat Diet: Effects on Plasma Lipid Concentrations and Body Composition in Hyperlipidemic Patients. American Journal of Clinical Nutrition, 59, 423-427.

[183] Kalman, D., Colker, C.M., Wilets, I., Roufs, J.B. and Antonio, J. (1999) The Effects of Pyruvate Supplementation on Body Composition in Overweight Individuals. Nutrition, 15, 337-340. http://dx.doi.org/10.1016/S0899-9007(99)00034-9

[184] Stanko, R.T., Tietze, D.L. and Arch, J.E. (1992) Body Composition, Energy Utilization, and Nitrogen Metabolism with a 4.25-MJ/d Low-Energy Diet Supplemented with Pyruvate. American Journal of Clinical Nutrition, 56, 630-635.

[185] Ojha, S., Goyal, S., Kumari, S. and Arya, D.S. (2012) Pyruvate Attenuates Cardiac Dysfunction and Oxidative Stress in Isoproterenol-Induced Cardiotoxicity. Experimental and Toxicologic Pathology, 64, 393-399. http://dx.doi.org/10.1016/j.etp.2010.10.004

[186] Izumi, Y., Katsuki, H. and Zorumski, C.F. (1997) Monocarboxylates (Pyruvate and Lactate) as Alternative Energy Substrates for the Induction of Long-Term Potentiation in Rat Hippocampal Slices. Neuroscience Letters, 232, 17-20. http://dx.doi.org/10.1016/S0304-3940(97)00567-3

[187] Kumashiro, N., Beddow, S.A., Vatner, D.F., et al. (2013) Targeting Pyruvate Carboxylase Reduces Gluconeogenesis and Adiposity and Improves Insulin Resistance. Diabetes, 62, 2183-2194. http://dx.doi.org/10.2337/db12-1311

[188] Martin, K.R. and Christy, L.A. (2010) Polyphenols as Dietary Supplements: A Double-Edged Sword. Nutrition and Dietary Supplements, 2, 1-12.

[189] Kimura, Y., Ito, H., Ohnishi, R. and Hatano, T. (2010) Inhibitory Effects of Polyphenols on Human Cytochrome P450 3A4 and 2C9 Activity. Food and Chemical Toxicology, 48, 429-435. http://dx.doi.org/10.1016/j.fct.2009.10.041

[190] Dai, G.L., He, L., Bu, P.L. and Wan, Y.J.Y. (2008) Pregnane X Receptor Is Essential for Normal Progression of Liver Regeneration. Hepatology, 47, 1277-1287. http://dx.doi.org/10.1002/hep.22129

[191] Calbet, J.A. and MacLean, D.A. (2002) Plasma Glucagon and Insulin Responses Depend on the Rate of Appearance of Amino Acids after Ingestion of Different Protein Solutions in Humans. Journal of Nutrition, 132, 2174-2182.

[192] Floyd, J.C., Fajans, S.S., Conn, J.W., Knopf, R.F. and Rull, J. (1966) Stimulation of Insulin Secretion by Amino Acids. Journal of Clinical Investigation, 45, 1487-1502. http://dx.doi.org/10.1172/JCI105456

[193] Zhang, Y.Y., Guo, K.Y., LeBlanc, R.E., Loh, D., Schwartz, G.J. and Yu, Y.H. (2007) Increasing Dietary Leucine Intake Reduces Diet-Induced Obesity and Improves Glucose and Cholesterol Metabolism in Mice via Multimechanisms. Diabetes, 56, 1647-1654. http://dx.doi.org/10.2337/db07-0123

[194] Guo, K.Y., Yu, Y.H., Hou, J. and Zhang, Y.Y. (2010) Chronic Leucine Supplementation Improves Glycemic Control in Etiologically Distinct Mouse Models of Obesity and Diabetes Mellitus. Nutrition \& Metabolism, 7, 57. http://dx.doi.org/10.1186/1743-7075-7-57

[195] Torres-Leal, F.L., Fonseca-Alaniz, M.H., Teodoro, G.F.R., et al. (2011) Leucine Supplementation Improves Adiponectin and Total Cholesterol Concentrations Despite the Lack of Changes in Adiposity or Glucose Homeostasis in Rats Previously Exposed to a High-Fat Diet. Nutrition \& Metabolism, 8, 62. http://dx.doi.org/10.1186/1743-7075-8-62

[196] Su, Y., Lam, T.K.T., He, W., Pocai, A., Bryan, J., Aguilar-Bryan, L. and Gutiérrez-Juárez, R. (2012) Hypothalamic Leucine Metabolism Regulates Liver Glucose Production. Diabetes, 61, 85-93. http://dx.doi.org/10.2337/db11-0857

[197] Zampieri, T.T., Pedroso, J.A.B., Furigo, I.C., Tirapegui, J. and Donato, J. (2013) Oral Leucine Supplementation Is Sensed by the Brain But Neither Reduces Food Intake Nor Induces an Anorectic Pattern of Gene Expression in the Hypothalamus. PLoS ONE, 8, e84094. http://dx.doi.org/10.1371/journal.pone.0084094

[198] (2014) REDD1-Linking GPCRs and mTOR. Journal of Cell Science, 127, e0405.

[199] Laplante, M. and Sabatini, D.M. (2012) mTOR Signaling in Growth Control and Disease. Cell, 149, $274-293$. http://dx.doi.org/10.1016/j.cell.2012.03.017

[200] Hsu, S.Y., Kudo, M., Chen, T., Nakabayashi, K., Bhalla, A., van der Spek, P.J., van Duin, M. and Hsueh, A.J.W. (2000) The Three Subfamilies of Leucine-Rich Repeat-Containing G Protein-Coupled Receptors (LGR): Identification of LGR6 and LGR7 and the Signaling Mechanism for LGR7. Molecular Endocrinology, 14, 1257-1271. http://dx.doi.org/10.1210/mend.14.8.0510

[201] Bjenning, C., Al-Shamma, H., Thomsen, W., Leonard, J. and Behan, D. (2004) G Protein-Coupled Receptors as Therapeutic Targets for Obesity and Type 2 Diabetes. Current Opinion in Investigational Drugs, 5, 1051-1062.

[202] Ghosh, H.S., McBurney, M. and Robbins, P.D. (2010) SIRT1 Negatively Regulates the Mammalian Target of Rapa- 
mycin. PLoS ONE, 5, e9199. http://dx.doi.org/10.1371/journal.pone.0009199

[203] Liu, M.L. and Liu, F. (2011) Resveratrol Inhibits mTOR Signaling by Targeting DEPTOR. Communicative \& Integrative Biology, 4, 382-384.

[204] Walker, D.K. (2006) Potential Importance of Leucine in Treatment of Obesity and the Metabolic Syndrome. Journal of Nutrition, 136, 319S-23S.

[205] Knapik, J., Meredith, C., Jones, B., Fielding, R., Young, V. and Evans, W. (1991) Leucine Metabolism during Fasting and Exercise. Journal of Applied Physiology, 70, 43-47.

[206] Layman, D.K. (2002) Role of Leucine in Protein Metabolism during Exercise and Recovery. Canadian Journal of Applied Physiology, 27, 646-662. http://dx.doi.org/10.1139/h02-038

[207] Crowe, M.J., Weatherson, J.N. and Bowden, B.F. (2006) Effects of Dietary Leucine Supplementation on Exercise Performance. European Journal of Applied Physiology, 97, 664-672.

[208] Roberts, C.K. and Barnard, R.J. (1985) Effects of Exercise and Diet on Chronic Disease. Journal of Applied Physiology, 98, 3-30. http://dx.doi.org/10.1152/japplphysiol.00852.2004

[209] Vinciguerra, M., Fulco, M., Ladurner, A., Sartorelli, V. and Rosenthal, N. (2010) SirT1 in Muscle Physiology and Disease: Lessons from Mouse Models. Disease Models \& Mechanisms, 3, 298-303. http://dx.doi.org/10.1242/dmm.004655

[210] Pardo, P.S. and Boriek, A.M. (2011) The Physiological Roles of Sirt1 in Skeletal Muscle. Aging (Albany NY), 3, 430437.

[211] Guichelaar, M.M. and Charlton, M.R. (2014) Decreased Muscle Mass in Nonalcoholic Fatty Liver Disease: New Evidence of a Link between Growth Hormone and Fatty Liver Disease? Hepatology. http://dx.doi.org/10.1002/hep.27058

[212] Flannery, C., Dufour, S., Rabøl, R., Shulman, G.I. and Petersen, K.F. (2012) Skeletal Muscle Insulin Resistance Promotes Increased Hepatic de Novo Lipogenesis, Hyperlipidemia, and Hepatic Steatosis in the Elderly. Diabetes, 61, 2711-2717. http://dx.doi.org/10.2337/db12-0206

[213] Gachona, F., Leuenberger, N., Claudel, T., Gos, P., Jouffe, C., Fleury Olela, F., de Mollerat du Jeu, X., Wahli, W. and Schibler, U. (2011) Proline- and Acidic Amino Acid-Rich Basic Leucine Zipper Proteins Modulate Peroxisome Proliferator-Activated Receptor $\alpha(\mathrm{PPAR} \alpha)$ Activity. Proceedings of the National Academy of Sciences of the United States of America, 108, 4794-4799. http://dx.doi.org/10.1073/pnas.1002862108

[214] Gachon, F., Olela, F.F., Schaad, O., Descombes, P. and Schibler, U. (2006) The Circadian PAR-Domain Basic Leucine Zipper Transcription Factors DBP, TEF, and HLF Modulate Basal and Inducible Xenobiotic Detoxification. Cell Metabolism, 4, 25-36. http://dx.doi.org/10.1016/j.cmet.2006.04.015

[215] Kritchevsky, D. (1985) Influence of Dietary Fiber on Xenobiotics. In: Xenobiotic Metabolism: Nutritional Effects, ACS Symposium Series, Vol. 277, Chapter 5, 51-60.

[216] Debethizy, J.D. and Goldstein, R.S. (1985) The Influence of Fermentable Dietary Fiber on the Disposition and Toxicity of Xenobiotics. In: Xenobiotic Metabolism: Nutritional Effects, ACS Symposium Series, Vol. 277, Chapter 4, 37-50.

[217] Martins, I.J. (2014) Nutrition and Genotoxic Stress Contributes to Diabetes and Neurodegenerative Diseases such as Parkinson's Disease and Alzheimer's Disease. Editors Bentham ebooks 2013, In: Atta-ur-Rahman, Ed., Frontiers in Clinical Drug Research-CNS and Neurological Disorders, Vol. 3, Chapter 1, 1-40.

[218] Wielgus, A.R. and Roberts, J.E. (2012) Retinal Photodamage by Endogenous and Xenobiotic Agents. Photochemistry Photobiology, 88, 1320-1345. http://dx.doi.org/10.1111/j.1751-1097.2012.01174.x

[219] Cheung, N. and Wong, T.Y. (2007) Obesity and Eye Diseases. Survey of Ophthalmology, 52, 180-195. 